\title{
DOCTRINA DEL TRIBUNAL CONSTITUCIONAL DURANTE EL TERCER CUATRIMESTRE DE 2020
}

Doctrine of the Constitutional Court during the third fourmonth period of 2020

\author{
JUAN CARLOS DUQUE VILLANUEVA \\ Tribunal Constitucional \\ duque@tribunalconstitucional.es
}

\section{CARLOS ORTEGA CARBALLO}

Tribunal Constitucional

ortega@tribunalconstitucional.es

\section{HERMINIO LOSADA GONZÁLEZ}

Tribunal Constitucional

losada@tribunalconstitucional.es

\section{TOMÁS DE LA QUADRA-SALCEDO JANINI \\ Tribunal Constitucional \\ tquadra@tribunalconstitucional.es}


I. JURISDICCIÓN CONSTITUCIONAL. DERECHO PROCESAL CONSTITUCIONAL.

II. FUENTES DEL DERECHO. III. ORGANIZACIÓN TERRITORIAL DEL ESTADO. IV. ORGANIZACIÓN DE LOS PODERES PÚBLICOS. V. DERECHOS FUNDAMENTALES.

\section{JURISDICCIÓN CONSTITUCIONAL. DERECHO PROCESAL CONSTITUCIONAL}

1. Durante el período que abarca esta crónica, escasas novedades relevantes presentan las decisiones dictadas por el TC en lo que a este apartado se refiere.

En relación con los recursos de inconstitucionalidad, se desestima en la STC 134/2020 (Pleno), de 23 de septiembre', la inadmisión parcial del recurso respecto de uno de los preceptos objeto de la demanda, pese a que no figuraba explícitamente citado en el acuerdo impugnatorio, al considerar el TC que la referencia en dicho acuerdo a «cualesquiera otros preceptos que, vinculados $\mathrm{o}$ no a los anteriores, vulneren principios constitucionales $\mathrm{o}$ invadan competencias de la comunidad autónoma» debía entenderse inclusiva de aquel precepto, cuyo contenido guardaba una estrecha relación con los que sí se mencionaban expresamente. A esta consideración se añade que el objeto del acuerdo de la Comisión Bilateral de Cooperación entre la Administración del Estado y la de la comunidad autónoma, a los efectos de la aplicación del art. 33.2 LOTC, había quedado delimitado en los términos del acuerdo previo impugnatorio, sin que se hubiera efectuado reparo alguno por parte de la Administración General del Estado. La estimación de la inadmisión parcial del recurso supondría, a juicio del TC, un rigorismo formal excesivo, porque podría «frustrar el interés público objetivo en que este tribunal desarrolle su función de garante supremo de la Constitución mediante el enjuiciamiento de la ley impugnada [...] una vez ha sido puesta de manifiesto la voluntad impugnatoria por quienes tienen constitucionalmente atribuida tal legitimación" (FJ 2).

$1 \quad$ Véanse, infra, pp. 242-245. 
En cuanto al plazo para la interposición del recurso de inconstitucionalidad, el TC recuerda en la STC 131/2020 (Pleno), de 22 de septiembre ${ }^{2}$, que la reforma de una ley abre naturalmente el plazo para que puedan ser impugnados los preceptos modificados en la nueva redacción que se les ha dado, pero que la parte de la ley que mantiene su redacción inicial resulta inatacable directamente por la vía del recurso de inconstitucionalidad cuando hayan transcurrido los plazos que establece el art. 33 LOTC para su impugnación (FJ 3).

Por su parte, en el ATC 174/2020 (Pleno), de 15 de diciembre, se inadmite por extemporáneo un recurso de inconstitucionalidad al haber transcurrido con creces el plazo de tres meses del art. 33 LOTC para su interposición, cuyo cómputo había quedado en suspenso por acuerdo del Pleno del TC de 16 de marzo de 2020 como consecuencia de la declaración del estado de alarma (Real Decreto 463/2020, de 15 de marzo). Suspensión que se levantó por posterior acuerdo de 6 de mayo de 2020, en el que se dispuso que los plazos para la interposición de nuevos recursos de toda clase de procesos constitucionales serían los establecidos en la LOTC, computándose desde su inicio, siendo, por lo tanto, el primer día del plazo el siguiente hábil al del levantamiento de la suspensión.

2. En las SSTC 149 y 150/2020 (Pleno), de 22 de octubre, el TC desestima los óbices de procedibilidad a la admisión a trámite de sendas cuestiones de inconstitucionalidad. En la primera de las sentencias considera que el órgano judicial ha formulado de manera adecuada el juicio de aplicabilidad y de relevancia, ya que ha puesto de manifiesto la interdependencia que existe entre la validez de la ley cuestionada y la resolución del recurso de reposición en el que debía pronunciarse sobre el mantenimiento o levantamiento de la suspensión del decreto objeto del proceso a quo que aquella ley derogó, de manera que su aplicación resultaba determinante de la decisión que había de tomar el órgano judicial respecto de la medida cautelar adoptada y sometida a revisión en el recurso de reposición. El TC entiende que los argumentos en los que se funda el juicio de aplicabilidad y relevancia «no son de manera notoria inconsistentes", por lo que han de considerarse debidamente efectuados. Esta conclusión conlleva que también estime que la cuestión se ha planteado en el momento procesal oportuno, al haberse promovido inmediatamente antes de dictar la decisión que ha de resolver el recurso de reposición en el incidente de medidas cautelares. Asimismo, el trámite de audiencia a las partes y al Ministerio Fiscal se entiende debidamente cumplimentado, pues,

2 Véase, infra, pp. 254-255. 
aunque en la providencia por la que se procedió a su apertura no se citaban los concretos preceptos cuestionados de la ley, su motivación permitía deducir que las dudas de constitucionalidad se proyectaban sobre toda la ley, sin que, a la vista de las alegaciones de las partes, se hubiese generado confusión alguna sobre el alcance de dichas dudas (FJ 2).

Por su parte, en la STC 150/2020, pese a que se califica de sucinta la fundamentación sobre el juicio de relevancia y se echa de menos un mayor esfuerzo argumental en su formulación, se considera que «lo relevante es que el razonamiento desarrollado en el auto planteando la cuestión de inconstitucionalidad aporte suficientes elementos expresivos del carácter determinante del proceso constitucional». En este caso, a juicio del TC, del auto se desprende que el órgano judicial «está revisando una sanción que se ha basado en un precepto legal que considera inconstitucional por vulnerar el principio de taxatividad o lex certa, y concluye que el fallo depende de la validez de dicho precepto legal», por lo que entiende debidamente formulado el juicio de relevancia.

No ha sido escaso el número de cuestiones de inconstitucionalidad que durante este cuatrimestre, al igual que viene sucediendo en los últimos, han sido inadmitidas por el incumplimiento de los requisitos procesales, aunque en algunas de ellas se aprecia, además, el carácter notoriamente infundado de la cuestión suscitada. Así, en el ATC 91/2020 (Pleno), de 9 de septiembre, se inadmite una cuestión porque el trámite de audiencia a las partes y al Ministerio Fiscal se llevó a cabo antes de que el órgano judicial practicase determinadas diligencias relevantes para determinar la aplicabilidad de la norma cuestionada al proceso a quo. Además, el referido trámite se omitió respecto a algunas de las partes del proceso. Y, en fin, el órgano judicial no formuló en el auto de planteamiento los juicios de aplicabilidad y relevancia.

En el ATC 93/2020 (Pleno), de 10 de septiembre, se inadmite otra cuestión de inconstitucionalidad al no satisfacerse los juicios de aplicabilidad y relevancia. En lo que atañe al primero, porque la duda de constitucionalidad en los términos en los que se suscita «adquiere una dimensión abstracta que es por completo ajena al procedimiento previsto en el art. $163 \mathrm{CE}$ », y, en cuanto al segundo, porque la duda de constitucionalidad no guarda relación con la cuestión planteada en el proceso a quo sobre la que debe pronunciarse el órgano judicial.

No son muy distintas las razones que conducen en el ATC 113/2020 (Pleno), de 22 de septiembre, a inadmitir otra cuestión de inconstitucionalidad. En primer lugar, por no haberse dado trámite de audiencia a la parte demandada en el proceso a quo, pese a que aún no había sido llamada al proceso cuando se procedió a su apertura. En este sentido, el TC recuerda que 
el hecho de que una de las partes no haya sido llamada al proceso «no exime al órgano judicial de otorgarte trámite de audiencia antes de plantear la cuestión de inconstitucionalidad», pues "[l]o determinante es que las partes, comparecidas $[. .$.$] o no, tengan la opción de ser oídas y expresar su parecer$ sobre una decisión de tanta entidad como el planteamiento de una cuestión de inconstitucionalidad», ya que "existe "un interés legítimamente protegido por nuestra Ley Orgánica en relación con las partes de un proceso ordinario para hacerse oír en el incidente previo que se considera"». A lo que ańade que en el auto de planteamiento se alega la infracción de preceptos constitucionales que no fue puesta de manifiesto en la providencia por la que se procedió al trámite de audiencia a las partes y al Ministerio Fiscal, no pudiendo deducirse de su motivación esas nuevas infracciones constitucionales que se aducen en el auto de planteamiento. Asimismo, el TC entiende que los juicios de aplicabilidad y relevancia no se han formulado de forma debida, al no resultar manifiesta la existencia de una verdadera dependencia o nexo de subordinación entre la decisión que tiene que adoptar el órgano judicial en el proceso a quo y la validez de la norma legal cuestionada.

En el ATC 144/2020 (Pleno), de 17 de noviembre, se califican de «insalvables deficiencias de carácter procesal» las que determinan la inadmisión de la cuestión de inconstitucionalidad. Tales deficiencias consistieron en que el órgano judicial tanto en el trámite de audiencia a las partes y al Ministerio Fiscal como en el auto de planteamiento no expone su propia duda de constitucionalidad, sino que se limita a recoger la argumentación en la que la parte actora sustentaba la solicitud de planteamiento de la cuestión, actuando el órgano judicial como «si fuera un simple emisario ajeno a este trámite [...], sin expresar su propia duda de constitucionalidad al respecto». A las expresadas deficiencias, se ańade que en la providencia por la que se procedió a la apertura del trámite de audiencia a las partes y al Ministerio Fiscal se omitió la mención a la norma legal de cuya constitucionalidad se duda, sin que, además, se hubiera dado participación a la parte demandante.

En relación con el orden de planteamiento de una cuestión prejudicial ante el Tribunal de Justicia de la Unión Europea (TJUE) y de una cuestión de inconstitucionalidad cuando al órgano judicial le suscite dudas la conformidad de la norma legal aplicable al derecho de la Unión y a la Constitución, el TC recuerda que ha de darse un tratamiento prioritario y preferente a la primera respecto a la segunda, ya que solo cuando haya quedado descartada la incompatibilidad de la norma legal con el derecho de la Unión se habrán despejado las dudas sobre su aplicabilidad y, en consecuencia, solo entonces procedería el planteamiento de la cuestión de inconstitucionalidad (AATC 90/2020 [Pleno], de 9 de septiembre; 115 y 116/2020 [Pleno], de 22 de 
septiembre, y 173/2020 [Pleno], de 15 de diciembre). Asimismo, el TC precisa que los requisitos del art. 35 LOTC deben cumplirse en el momento de plantear la cuestión de inconstitucionalidad, es decir, cuando se dicta el auto de planteamiento, de modo que la decisión de dejar en suspenso el trámite de elevar la cuestión al TC una vez dictado dicho auto hasta que se resuelva la cuestión prejudicial por el TJUE impide estimar cumplimentados los requisitos procesales para promover la cuestión de inconstitucionalidad, lo que determina, por consiguiente, su inadmisión (ATC 90/2020 [Pleno]).

3. El objeto de un conflicto de competencias lo constituyen las normas, disposiciones o actuaciones identificadas por el promotor del proceso en el acuerdo impugnatorio, sin que pueda pretenderse en la demanda su extensión a normas, disposiciones y actuaciones distintas a las delimitadas por la parte actora. Así lo ha apreciado el TC en la STC 135/2020 (Pleno), de 23 de septiembre ${ }^{3}$, que resuelve el conflicto positivo de competencia planteado por el Gobierno en relación con el acuerdo del Gobierno de la Generalitat de Cataluña por el que se aprueba el plan estratégico de acción exterior y de relaciones con la Unión Europea 2019-2020 y se acuerda su envío al Parlamento.

El TC desestima que puedan ser objeto del proceso, como pretendía el abogado del Estado, «actuaciones que se sitúan extramuros del presente conflicto, delimitado en los términos formulados en el previo requerimiento de incompetencia [...] y en el posterior acuerdo del Consejo de Ministros en el que se decide el planteamiento del conflicto", que únicamente se refiere a aquel plan. Tales actuaciones, entiende el TC, no pueden traerse de manera indirecta a este proceso, al no ser ejecución del plan impugnado, cuya vigencia y aplicación se encontraban suspendidas ex art. 161.2 CE, de modo que si se consideraba que eran contrarias al orden constitucional y estatutario de distribución de competencias deberían haber sido impugnadas ante la jurisdicción ordinaria o ante este tribunal (FJ 3.a).

4. Los motivos de especial trascendencia constitucional apreciados en los recursos de amparo resueltos durante este cuatrimestre han sido los siguientes:

a) (STC 155/2009, FJ 2.a) que el recurso plantea un problema o afecta a la faceta de un derecho fundamental sobre el que no ha doctrina del TC (SSTC 102/2020 [Sala Primera], de 21 de septiembre —inadmisión no motivada de incidente de nulidad de actuaciones

3 Véanse, infra, pp. 245-248. 
en el que se solicita planteamiento de cuestión de inconstitucionalidad- ${ }^{4}$; 103/2020 [Sala Primera], de 25 de octubre —utilización de la dirección electrónica habilitada como cauce de comunicación del primer emplazamiento en proceso de ejecución hipotecaria- ${ }^{5} ; 120$, 128 y 129/2020 [Sala Primera], de 21 de septiembre, y 168/2020 [Sala Segunda], de 16 de noviembre - discriminación por razón de sexo en cómputo de descanso retribuido que ignora la reducción de jornada para el cuidado de hijos menores- ${ }^{6}$; 141/2020 [Sala Segunda], de 6 de octubre — resoluciones judiciales que impiden el control jurisdiccional de embargo acordado por la Administración tributaria—; 143/2020 [Sala Segunda], de 19 de octubre —inadmisión de incidente de nulidad de actuaciones por falta de interposición de recurso de casación y extraordinario por infracción procesal—; 147/2020 [Sala Primera], de 19 de octubre — solicitud de extradición no respaldada en una orden judicial de detención o prisión-; 161/2020 [Sala Segunda], de 16 de noviembre — denegación de la modificación de la liquidación de condena de la pena de inhabilitación especial para el ejercicio del derecho de sufragio pasivo-; 165/2020 [Sala Segunda], de 16 de noviembre —incidencia en los derechos a la tutela judicial efectiva y de defensa del incumplimiento por la Administración sanitaria del deber de custodia del historial clínico del paciente-; 180/2020 [Sala Primera], de 14 de diciembre — garantía de acceso a los elementos esenciales de las actuaciones en la adopción de prisión provisional-;

4 También se apreció como motivo de especial trascendencia constitucional que la vulneración del derecho fundamental que se denuncia pudiera provenir de la ley o de otra disposición de carácter general (STC 155/2009, FJ 2. c).

5 También se apreció este motivo de especial trascendencia constitucional en las SSTC 104, 105, 112, 113, 116, 117/2020 (Sala Primera) y 110, 111/2020 (Sala Segunda), de 21 de septiembre, y 133/2020 (Pleno), de 25 de octubre.

Junto con este motivo de especial trascendencia, también se apreció como motivo de especial trascendencia constitucional que el recurso puede dar ocasión al Tribunal para aclarar o cambiar su doctrina como consecuencia de cambios normativos relevantes en la configuración del contenido del derecho fundamental (STC 155/2009, FJ 2.b) en las SSTC 114, 115, 118, 121, 122, 123, 127/2020 (Sala Segunda), de 21 de septiembre, 138, 139, 146/2020 (Sala Segunda), de 6 de octubre, 158/2020 (Sala Segunda), de 4 de noviembre, y 174 y 175/2020 (Sala Segunda), de 30 de noviembre.

6 También se apreció como motivo de especial trascendencia constitucional que el recurso puede dar ocasión al TC para aclarar o cambiar su doctrina como consecuencia de un proceso de reflexión interna (STC 155/2009, FJ 2.b). 
190/2020 [Pleno], de 15 de diciembre — respuesta penal a un mensaje de menosprecio a la bandera espańola—; 192/2020 [Pleno], de 17 de diciembre — respuesta penal a la interrupción de una ceremonia religiosa con consignas a favor del derecho al aborto-, y 193, 194 y 195/2020 [Pleno], de 17 de diciembre —-suspensión de cargo público en aplicación del art. 384 bis LECrim- $^{7}$ ).

b) (STC 155/2009, FJ b) que el recurso puede dar ocasión al TC para aclarar o cambiar su doctrina como consecuencia de un proceso de reflexión interna (SSTC 124/2020 [Sala Primera], de 21 de septiembre - discriminación por razón de sexo en cómputo de descanso retribuido que ignora la reducción de jornada para el cuidado de hijos menores-; 132/2020 [Pleno], de 23 de septiembre — solicitud de extradición en la que no consta la renuncia inequívoca del acusado a estar presente en el juicio penal que lo condenó-; 142/2020 [Sala Segunda], de 19 de octubre — condena desproporcionada por las expresiones utilizadas por una abogado en la defensa de su cliente-, y 160/2020 [Sala Segunda], de 16 de noviembre —atribución de efectos interruptivos de la prescripción a notificaciones defectuosas practicadas por la Administración tributaria-).

c) (STC 155/2009, FJ b) que el recurso puede dar ocasión al TC para aclarar o cambiar su doctrina como consecuencia del surgimiento de nuevas realidades sociales (STC 178/2020 [Sala Segunda], de 14 de diciembre — solicitud de alteración del orden legal de los apellidos de una menor cuya filiación paterna fue declarada judicialmente-).

d) (STC 155/2009, FJ b) que el recurso puede dar ocasión al TC para aclarar o cambiar su doctrina como consecuencia de cambios normativos relevantes para la configuración del contenido del derecho (SSTC 125/2020 [Sala Segunda], de 21 de septiembre ${ }^{8}$, y 167/2020 [Sala Primera], de 16 de noviembre -emplazamiento edictal en procesos de ejecución hipotecaria y divorcio-, y 126/2020 [Sala Primera], de 21 de septiembre —utilización de la dirección

7 En las SSTC 193 y 194/2020 también se apreció como motivo de especial trascendencia constitucional que la vulneración del derecho fundamental que se denuncia pudiera provenir de la ley o de otra disposición de carácter general (STC 155/2009, FJ 2.c).

8 También se apreció como motivo de especial trascendencia constitucional que el órgano judicial pudiera haber incurrido en una negativa manifiesta del deber de acatamiento a la doctrina de este Tribunal (STC 155/2009, FJ 2.f). 
electrónica habilitada como cauce de comunicación del primer emplazamiento en proceso de ejecución hipotecaria- ${ }^{9}$ ).

e) (STC 155/2009, FJ 2.c) la posible vulneración del derecho fundamental que se denuncia pudiera provenir de la ley o de otra disposición de carácter general (SSTC 145/2020 [Sala Primera], de 19 de octubre, 162/2020 [Sala Segunda], 163 y 164/2020 [Sala Primera], de 16 de noviembre, 179/2020 [Sala Primera], de 14 de diciembre, y 182/2020 [Sala Segunda], de 14 de diciembre —impugnabilidad de decretos de los letrados de la Administración de justicia-; 137/2020 [Sala Segunda], de 6 de octubre, 166/2020 [Sala Primera], de 16 de noviembre, y 177/2020 [Sala Segunda], de 14 de diciembre —-denegación de indemnización por prisión provisional en causa penal seguida de absolución-, y 191/2020 [Pleno], de 17 de diciembre - precepto reglamentario que limita el disfrute de becas a los alumnos matriculados en universidades públicas-).

f) (STC 155/2009, FJ 2.e) que la doctrina de este Tribunal sobre el derecho fundamental que se alega podría estar siendo incumplida de modo general y reiterado por la jurisdicción ordinaria o pudieran existir resoluciones judiciales contradictorias sobre el derecho fundamental (STC 155/2020 [Sala Segunda], de 4 de noviembre - falta de legitimación del titular de una farmacia para reclamar al servicio de salud el retraso en el pago de medicamentos suministrados por no ser parte del convenio suscrito entre el servicio de salud y el colegio de farmacéuticos-).

g) (STC 155/2009, FJ 2.f) que el órgano judicial pudiera haber incurrido en una negativa manifiesta del deber de acatamiento de la doctrina de este Tribunal (SSTC 119/2020 [Sala Primera], de 21 de septiembre, y 187/2020 [Sala Segunda], de 14 de diciembre —emplazamiento edictal en procesos de despido y de ejecución hipotecaria-, y 181/2020 [Sala Primera], de 14 de diciembre — denegación de incoación de procedimiento de habeas corpus-).

h) (STC 155/2019, FJ 2.g) que el recurso plantea una cuestión de relevante y general repercusión social o económica (SSTC 106 y 109/2020 [Sala Primera], 107 y 108/2020 [Sala Segunda], de 21 de septiembre,

9 También se apreció este motivo de especial trascendencia constitucional en las SSTC 130/2020 (Sala Primera), de 21 de septiembre; 156, 157 y 159/2020 (Sala Segunda), de 4 de noviembre; 169 y 170/2020 (Sala Primera), de 16 de noviembre; 176/2020 (Sala Segunda), de 30 de noviembre, y 183, 184, 185, 186, 188 y 189/2020 (Sala Primera), de 14 de diciembre. 
136 y 144/2020 [Sala Segunda], de 6 y 19 de octubre, respectivamente - inadmisión de recurso de casación por infracción de normativa autonómica-, y 140/2020 [Sala Segunda], de 6 de octubre —ausencia de control de cláusulas abusivas que desconoce la primacía del derecho de la Unión Europea y la jurisprudencia del Tribunal de Justicia-).

i) (STC 155/2019, FJ g) que el asunto suscitado trasciende del caso concreto porque pudiera tener unas consecuencias políticas generales (STC 173/2020 [Pleno], de 19 de noviembre — acuerdos de la presidenta y de la mesa del Parlamento por los que se posponen la celebración de sesiones plenarias de la Cámara-).

Una sistematización de la doctrina sobre el requisito de la especial trascendencia constitucional se recoge en el ATC 149/2020 (Sección Primera), de 26 de noviembre (FJ 2), del que resulta llamativa la afirmación de que la reforma de la LOTC llevada a cabo por la Ley Orgánica 6/2007, de 24 de mayo, «ha eliminado la dimensión subjetiva del recurso de amparo para dotarlo, exclusivamente, de un significado objetivo». Afirmación, que si bien está tomada de resoluciones precedentes (AATC 29/2011, de 17 de marzo, FJ 3, y 47/2018, de 25 de abril, FJ 2), claramente contrasta con pronunciamientos anteriores del TC, según los cuales «[e]l recurso de amparo, en todo caso, sigue siendo un recurso de tutela de los derechos fundamentales», que se contiene, entre otras, en la STC 155/2009, de 25 de junio (FJ 2). Precisamente es esta la sentencia en la que, tras referirse a la nueva configuración que el legislador ha efectuado del recurso de amparo, se esboza sin ánimo exhaustivo el elenco de supuestos en los que puede tener especial trascendencia constitucional. En el mismo sentido, pero con otras palabras, también se ha dicho que tras la reforma legislativa del año 2007 el recurso de amparo «no ha perdido su dimensión subjetiva como instrumento procesal para preservar o restablecer las violaciones de derechos y libertades fundamentales» (SSTC 2/2013, de 14 de enero, FJ 3; 203/2015, de 5 de octubre, FJ 2; 1/2020, de 14 de enero, FJ 2, y 56/2019, de 6 de mayo, FJ 2).

En relación con la causa de especial trascendencia constitucional de que la posible vulneración del derecho fundamental que se denuncia pudiera provenir de la ley o de otra disposición de carácter general (STC 155/2009, FJ 2.c), el TC declara en la STC 162/2020 (Sala Primera), de 16 de noviembre, que, dada su naturaleza abstracta y desconectada de una situación particular concreta, "ha sido flexible en validar una argumentación que objetive el recurso argumentando las dudas sobre la constitucionalidad de la norma que se trate [...] siempre que se ponga de relieve por el recurrente la lesión de sus derechos que puede tener origen en la propia ley» (FJ 2.iv). 
En fin, durante este cuatrimestre se han seguido explicitando en la fundamentación jurídica de algunas de las sentencias, con invocación en ocasiones de la doctrina de la STEDH de 20 de enero de 2015 (asunto Arribas Antón c. España), las razones por las que se estima que concurren el motivo o los motivos de especial trascendencia constitucional apreciados en el trámite de admisión de la demanda, que quedan reflejados en los antecedentes (SSTC 141/2020 [Sala Segunda], de 6 de octubre; 143/2020 [Sala Segunda], de 19 de octubre; 147/2020 [Sala Primera], de 19 de octubre, y 132/2020 [Pleno], de 23 de septiembre).

5. El TC ha confirmado en la en la STC 173/2020 (Pleno), de 19 de noviembre, frente al óbice de admisibilidad alegado por el Ministerio Fiscal con base en el tenor literal del 42 LOTC, que a través del recurso de amparo parlamentario son susceptibles de impugnación no solo los actos o decisiones sin valor de ley de los órganos de las Cámaras, sino también las omisiones o simple vía de hecho que pudieran resultar lesivas de derechos fundamentales que pueden ser objeto del recurso de amparo. A la luz del art. 41.2 LTC, que prevé con carácter general que el recurso de amparo en sus diversas modalidades protege frente a violaciones de derechos fundamentales originadas por "disposiciones, actos jurídicos, omisiones o simples vías de hecho», no hay razones — se afirma en la sentencia - "para interpretar que el recurso de amparo parlamentario no pueda interponerse contra omisiones o simple vía de hecho de los órganos parlamentarios", que puedan tener como consecuencia la vulneración de alguno de esos derechos fundamentales (FJ 2.b).

En la sentencia se desestima, entre otras, la impugnación de la decisión de la mesa del Parlamento de Cataluña por la que se acuerda posponer la celebración de una sesión plenaria prevista inicialmente para los días 20 y 21 de septiembre de 2017 a los días 20 y 21 de diciembre de ese mismo año. Decisión que los recurrentes vinculan a la tramitación de una moción que habían presentado y había sido admitida a trámite sobre el referéndum de autodeterminación convocado para el día 1 de octubre de 2017. La desestimación se funda, como primer motivo, en el incumplimiento del requisito del art. 49.1 LOTC, al sustentar el grupo parlamentario demandante la lesión del derecho al ejercicio del cargo público representativo (art. 23.2 CE) en un argumentación genérica, inconcreta y abstracta. Razonamiento que no deja de sorprender cuando en la demanda se vincula la decisión de posponer la sesión plenaria a evitar la tramitación de aquella moción que el grupo parlamentario había presentado en relación con la celebración en fechas próximas del referéndum de autodeterminación.

La no interposición de una solicitud de reconsideración contra el citado acuerdo de la mesa es el segundo argumento en el que se funda la 
desestimación de la queja del grupo parlamentario demandante, no solo a los efectos de estimar debidamente agotada la vía parlamentaria interna previa al recurso de amparo (art. 42 LOTC), sino también a fin de que la parte actora dispusiera de una «base argumentativa suficiente para impugnar un acto que, en principio, fue acordado con respeto al procedimiento reglamentario establecido para modificar la fecha de la sesión del Pleno de la Cámara» (art. 81 RPC). El TC entiende que aquel acuerdo era susceptible de solicitud de reconsideración, con base en los preceptos del reglamento que la regulan en relación con las funciones de la mesa de calificar y declarar la admisión de los escritos y documentos de índole parlamentaria y de decidir sobre su tramitación (art. 37.3.d y e RPC). Considera, además, que su interposición era necesaria para que la mesa pudiera exponer de forma razonada los motivos que determinaron la decisión recurrida, "pues dicha motivación resulta necesaria para que este tribunal dirima, en su caso, si la decisión de la mesa responde a razones técnicas y de naturaleza organizativa o, si por el contrario, se ha extralimitado en sus funciones». Sin esa motivación —-concluye en este punto la sentencia-, «este tribunal no puede aventurarse en conjeturas sobre la intencionalidad del cambio de fecha, aunque el fiscal [...] afirme que [...] responde a "un fin ilegítimo o espurio que impide el desarrollo de la actividad parlamentaria y la condiciona por un referéndum suspendido por el Alto Tribunal"» (FJ 3). Prescindiendo de la pertinencia en este caso de la solicitud de reconsideración, cuya exigencia pudiera resultar un tanto rigurosa teniendo en cuenta la decisión cuestionada - posponer una sesión plenaria prevista para una fecha determinada - y los concretos supuestos para los que está contemplada en el reglamento la solicitud de reconsideración — acuerdos de la mesa sobre calificación, admisión a trámite y tramitación de documentos e iniciativas parlamentarias-, no deja de resultar llamativo el argumento de que el TC no puede dirimir la existencia o no de la lesión del derecho fundamental denunciada sin conocer las razones por las que se ha adoptado la decisión de posponer la sesión plenaria, pues parece convertir lo que, en principio, es una obligación de los órganos parlamentarios, como es la motivación de las decisiones que puedan incidir en el ejercicio de los derechos de los miembros de la Cámara, en una carga de estos de provocar dicha motivación.

6. En la STC 191/2020 (Pleno), de 17 de diciembre ${ }^{10}$, se reconoce a una universidad privada legitimación para interponer recurso de amparo, por vulneración de los derechos a la igualdad (art. 14 CE) y a la creación de centros docentes (art. 27.6 CE), contra el precepto de una orden de la Conselleria de

10 Véanse, infra, pp. 256-257. 
Educación, Investigación, Cultura y Deportes de la Generalitat Valenciana que restringe el disfrute de becas a los alumnos matriculados en universidades públicas integrado en el sistema universitario valenciano.

El TC argumenta al respecto que el precepto impugnado, al excluir a los alumnos de las universidades privadas como beneficiarios de las becas, "puede producir un efecto desalentador en la matriculación de nuevos alumnos» en la universidad recurrente, así como «la pérdida de alumnos matriculados», lo que le puede generar un perjuicio evidente. Si bien los destinatarios de las becas son los alumnos y no la universidad, su exclusión concierne tanto al derecho del titular de la universidad recurrente en amparo a crear instituciones educativas (art. 27.6 CE) como al derecho a la educación de los estudiantes matriculados en dicha universidad (art. 27.5 CE) (FJ 2.a).

También se estima como objeto idóneo del recurso de amparo la orden impugnada, ya que el trato desigual o discriminatorio que se le imputa tiene su origen directo e inmediato en la misma orden, sin necesidad de posteriores actos aplicativos. En otras palabras, la «índole simplemente impeditiva de la disposición atacada permite imputarle directamente, sin necesidad de acto alguno de aplicación», la lesión que la demandante pretende haber sufrido en sus derechos fundamentales (FJ 2.b $)^{11}$.

11 A la sentencia formularon sendos votos particulares la magistrada Balaguer Callejón y los magistrados Xiol Ríos y Conde-Pumpido Tourón. En lo que a este apartado de la crónica interesa, el magistrado Xiol Ríos y la magistrada Balaguer Callejón sostienen en el voto que suscriben conjuntamente, en síntesis, que la universidad recurrente carece de legitimación para interponer el recurso, ya que «no acude a este proceso en defensa de sus derechos fundamentales, sino de los derechos fundamentales de sus estudiantes», y aunque la orden impugnada pudiera causarle algún perjuicio, este «nunca incidiría en su derecho a la igualdad ni en su derecho a la creación de centros docentes, pues el diferente trato que establece la orden impugnada no afecta directamente a las universidades, sino a los estudiantes, que son los beneficiarios de estas ayudas». De otra parte, consideran que la orden impugnada no puede ser objeto de recurso de amparo al no tener carácter autoaplicativo, de modo que hasta que no se lleven a cabo las correspondientes convocatorias de las becas el trato diferente entre estudiantes de universidades privadas y públicas «no ocasionaría ninguna lesión real y efectiva de los derechos fundamentales invocados».

El magistrado Conde-Pumpido Tourón entiende también que serían los estudiantes, en su caso, no la universidad recurrente, los legitimados para impugnar la orden, al ser los titulares del derecho fundamental que se denuncia como vulnerado, pues son los destinatarios de las becas. La universidad carece de legitimación al no ser la titular del derecho fundamental en juego, «sin que puedan interponer recurso de amparo las personas físicas o jurídicas en relación con supuestas vulneraciones de derechos 
7. El TC insiste en la STC 102/2020 (Sala Primera), de 21 de septiembre, en la función esencial que desempeña el incidente de nulidad de actuaciones, tras la nueva configuración del recurso de amparo por la Ley Orgánica 6/2007, de 24 de mayo, en la tutela y defensa de los derechos fundamentales, por lo que ha de controlar las hipotéticas lesiones de derechos que se produzcan en el incidente cuando tengan especial relevancia constitucional. Recuerda, asimismo, que los órganos judiciales han de realizar una interpretación restrictiva de los motivos de inadmisión del incidente, debiendo tramitarlo y motivar suficientemente las decisiones de inadmisión, pues cuando es procedente su interposición afectan a una pretensión de tutela de los derechos fundamentales ante la jurisdicción ordinaria. Aunque no se trata propiamente de un recurso, el canon de control de estas decisiones es el propio del derecho de acceso al recurso, de forma que se ha de constatar si la resolución dictada está motivada y ha incurrido o no en error material patente, arbitrariedad o manifiesta irrazonabilidad.

Con base en la doctrina reseñada, el TC estima lesiva del derecho a la tutela judicial efectiva (art. 24.1 CE) en la citada sentencia la inadmisión inmotivada de un incidente de nulidad de actuaciones, en el que se solicitaba el planteamiento de una cuestión de inconstitucionalidad, pues, aunque las partes no tengan derecho a su planteamiento, el órgano judicial debe «exteriorizar de manera suficiente y adecuada el razonamiento que, desde la perspectiva tanto fáctica como jurídica», le ha llevado a decidir no suscitar la cuestión de inconstitucionalidad.

Más relevante que el sentido de este pronunciamiento es la afirmación que se hace en la sentencia, sin referencia a base fáctica o estadística alguna que la sustente, sobre la habitualidad con que los órganos judiciales dictan decisiones de inadmisión de incidentes de nulidad carentes de motivación, lo «que pone de manifiesto — según el TC—que los órganos de la jurisdicción ordinaria no otorgan al incidente de nulidad de actuaciones la importancia que quiso darle el legislador orgánico [...] y sobre la que ha insistido nuestra doctrina, pues, con demasiada frecuencia, se procede a inadmitir dicho

fundamentales de terceros». La consecuencia de la estimación del recurso de amparo nunca podría ser, por lo tanto, el reconocimiento de la vulneración de un derecho de la propia universidad, sino el derecho de los estudiantes como beneficiarios de la becas. Asimismo, estima que la lesión no sería imputable directamente a la orden impugnada, sino a las respectivas convocatorias, que serán las que determinarán, en su caso, la exclusión de los alumnos de las universidades privadas, de modo que la vulneración de derechos fundamentales que se denuncia es «meramente potencial o hipotética», no «efectiva, real y concreta». 
incidente con una fórmula estereotipada y manifiestamente insuficiente desde la perspectiva del derecho de los justiciables a recibir una resolución motivada y fundada en Derecho» (FJ 6). La genérica atribución a los órganos judiciales de un comportamiento como el descrito se debería sustentar, por prudencia, ya que se ha considerado conveniente su exteriorización, en datos fácticos suficientemente constatados, máxime si se tiene en cuenta que las resoluciones judiciales recurridas en amparo suponen cuantitativamente un porcentaje bastante insignificante en relación con el número de las que dictan los órganos judiciales en los cuantiosos procesos judiciales de los que conocen.

8. En relación con el agotamiento de la vía judicial previa al recurso amparo (art. 44.1.a LOTC), no es exigible la interposición de los recursos de casación y extraordinario por infracción procesal, en vez de acudir al incidente de nulidad de actuaciones, cuando en opinión de la parte actora no concurran los motivos previstos en la ley para la interposición de dichos recursos con arreglo a consolidados criterios interpretativos del Tribunal Supremo (STC 143/2020 [Sala Segunda], de 19 de septiembre, FF. JJ. 4 y 5).

De otra parte, el TC ha considerado en la STC 162/2020 (Sala Segunda), de 16 de noviembre, que la no interposición del incidente de nulidad de actuaciones contra la decisión del órgano judicial de inadmitir un recurso de revisión, por no estar previsto legalmente recurso alguno contra los decretos dictados por el letrado de la Administración de justicia (art. 454 bis 1 LEC), no implica la falta de agotamiento de la vía judicial previa, pues entiende que, dadas las razones en las que se funda la inadmisión, «no resultaba necesario reiterar los motivos determinantes de la vulneración del derecho a la tutela judicial efectiva» mediante la interposición del incidente (FJ 2.i).

Para intentar la reparación en la vía judicial de una incongruencia omisiva son remedios procesales idóneos tanto el incidente de nulidad de actuaciones como el complemento de sentencia, de modo que la interposición de cualquier de ellos es suficiente para considerar debidamente agotada la vía judicial previa (STC 165/2020 [Sala Segunda], de 16 de noviembre, FJ 2.b) ${ }^{12}$.

En fin, en aplicación de la doctrina de la STC 121/1989, de 28 de octubre (FJ 2), y del ATC 98/2010, de 19 de julio, el TC estima en la STC 166/2020 (Sala Primera), de 16 de noviembre, que la inadmisión de un recurso de casación por el Tribunal Supremo, al considerar que el escrito de preparación «contenía una justificación insuficiente —que no inexistente— de su interés

12 Véanse, infra, pp. 267-268. 
casacional objetivo", no puede entenderse que obedeciera a un defecto procesal manifiesto o incontrovertible atribuible de forma clara e inequívoca a la falta de diligencia de la parte, razón por la que la vía judicial previa debe entenderse debidamente agotada en este caso (FJ 2.c).

9. En materia de medidas cautelares, el ATC 146/2020 (Pleno), de 17 de noviembre, deniega la suspensión de la resolución judicial que condena al recurrente en amparo - presidente de la Generalitat de Cataluña-, como autor de un delito de desobediencia, a las penas de multa e inhabilitación especial para el ejercicio de cargo público electivo y para el desempeño de funciones de gobierno. El TC considera que la suspensión solicitada no impediría la pérdida del cargo de presidente de la Generalitat «toda vez que el recurrente lo ha perdido definitivamente mediante la declaración de firmeza de la sentencia y su consiguiente ejecución", tratándose, en consecuencia, "de una pena que se ejecuta y agota en un solo acto». Además, en relación con los perjuicios irreparables que aduce el recurrente, entiende que la puesta en marcha del procedimiento parlamentario para la provisión del cargo de presidente y, en su caso, la convocatoria de elecciones si aquel procedimiento no culmina con éxito son efectos jurídicos que nada tienen que ver con la condena del recurrente, «sino que obedecen al cumplimiento de la normativa vigente reguladora del funcionamiento ordinario de las instituciones, que han de ejercitar sus respectivas competencias en aquellas situaciones que así lo requieran»; es decir, «se trata de efectos jurídicos que se han generado al margen de la sentencia del Tribunal Superior de Justicia de Cataluña firme que le impuso la condena». En cuanto al efecto de la condena sobre la imposibilidad de obtener o ser elegido para el mismo cargo u otro de carácter análogo, la dificultad de su reparación, en caso de ser estimado el recurso de amparo, no impediría esta, «si el recurso se resuelve - como es previsible - antes de que finalice el periodo de condena», no siendo real o evidente el perjuicio que se invoca, a juicio del TC, ya que en el momento de dictarse el auto no se ha convocado proceso electoral alguno al que pudiera concurrir el demandante como candidato. Tras resaltar las diferencias existentes con los precedentes jurisprudenciales invocados por el demandante, el TC estima que la adopción de la medida de suspensión solicitada «supondría una perturbación grave de un interés protegido constitucionalmente, como es la garantía de la efectividad de la actuación de los poderes públicos, en este caso del Poder Judicial (art. 117.3 CE)», ante un asunto que presenta contornos singulares, ya que el recurrente ha sido condenado como autor de un delito de desobediencia "por el incumplimiento reiterado y contumaz de los requerimientos de un órgano como la Junta Electoral 
Central, cuya función es "garantizar [...] la transparencia y objetividad del proceso electoral y del principio de igualdad" ${ }^{13,14}$.

\section{FUENTES DEL DERECHO}

1. El problema de las leyes singulares autoaplicativas ha sido abordado por el TC en dos sentencias durante el cuatrimestre que nos ocupa, dictadas ambas en procesos de declaración de inconstitucionalidad referidos a una misma ley autonómica, la Ley 9/2019, de 28 de marzo, de modificación de la Ley 4/1996, de 12 de julio, de caza en la Comunidad Autónoma de Castilla y León. Se trata de la STC 148/2020 (Pleno), de 22 de octubre ${ }^{15}$, que desestima el recurso de inconstitucionalidad formulado por el Defensor del Pueblo en relación con diversos preceptos de aquella ley, y de la STC 149/2020 (Pleno), de 22 de octubre, que desestima la cuestión de inconstitucionalidad planteada por la Sala de lo Contencioso-Administrativo del Tribunal Superior de Justicia de Castilla y León contra la misma ley autonómica.

Para dar respuesta a la tacha esgrimida por el Defensor del Pueblo referida a que la ley impugnada vulnera los arts. 9.3 CE, que proscribe la arbitrariedad, y 24.1 CE, por tratarse de una ley singular que no se ajusta a los límites constitucionales, la STC 148/2020, FJ 5, comienza por recordar la reiterada doctrina constitucional sobre las denominadas «leyes singulares», que no son, per se, inconstitucionales, si bien, al no constituir un ejercicio normal de la potestad legislativa, están sujetas a una serie de límites contenidos en la propia Constitución. Esa doctrina ha clasificado las «leyes singulares» en tres grandes tipos: 1) leyes singulares «autoaplicativas», término este que hace alusión a las leyes que contienen una actividad típicamente ejecutiva, de aplicación de la norma al caso concreto; 2) leyes «de estructura singular», en atención a los destinatarios a los que van dirigidas, y 3) leyes dictadas en atención a un supuesto de hecho concreto y singular, que agotan su contenido y eficacia en la adopción y ejecución de la medida tomada por el legislador

13 Al auto formuló voto particular discrepante el magistrado Xiol Ríos, para quien el hecho de que se haya dado comienzo a la ejecución de la pena de inhabilitación no impedía «acordar su suspensión en relación con los efectos no agotados». Además considera que en este caso «no existen elementos diferenciales que justifiquen apartarse de los precedentes, por lo que, de acuerdo con la jurisprudencia constitucional, hubiera debido otorgarse la medida cautelar solicitada».

14 Juan Carlos Duque Villanueva.

15 Véanse, infra, pp. 248-250. 
ante ese supuesto de hecho, aislado en la ley singular y no comunicable a ningún otro.

Partiendo de esa doctrina, la STC 148/2020 concluye que la ley impugnada no constituye un supuesto de ley singular autoaplicativa, porque para que una ley merezca esa calificación no basta con que pueda aplicarse directamente sin precisar desarrollo reglamentario ni actos intermedios de aplicación, sino que es preciso, además, que a través de la ley se realice una actividad «materialmente administrativa» o «típicamente ejecutiva, de aplicación de la norma al caso concreto", requisitos que el TC no aprecia que se cumplan en este caso, pues las determinaciones de la ley autonómica impugnada «regulan con carácter general y abstracto la actividad cinegética en Castilla y León, sin que su eficacia se agote con la aplicación a un caso concreton; el ejercicio de esa actividad cinegética exige de actuaciones administrativas concretas previstas en la propia ley. Tampoco puede calificarse la ley impugnada — prosigue el TC - como ley de destinatario único o de estructura singular, "pues sus previsiones van dirigidas a una pluralidad indeterminada de sujetos, que incluyen tanto a los que pretendan llevar a cabo la actividad regulada, como a las administraciones competentes que han de desarrollar las actuaciones y adoptar las resoluciones necesarias para garantizar el adecuado cumplimiento de lo señalado en la ley». El TC descarta, asimismo, que se trate de una ley singular dictada en relación con un supuesto de hecho concreto y singular que agote su contenido en la adopción de la medida establecida por el legislador: por el contrario, se trata de una ley «que nace con vocación de permanencia, que se proyecta hacia el futuro y que es susceptible de una pluralidad de aplicaciones».

En fin, la STC 148/2020 concluye descartando también que estemos ante un supuesto de ley singular mediante la cual se pretendiera enervar la medida cautelar suspensiva adoptada por el órgano judicial, respecto del reglamento autonómico que desarrolla la Ley de Caza de Castilla y León de 2016, en el proceso contencioso-administrativo contra esa norma reglamentaria que se hallaba pendiente de resolución al momento de aprobarse la Ley 9/2019. Aprecia el TC, a la vista de lo indicado en la exposición de motivos de la ley, que el legislador autonómico ha establecido la regulación de la actividad cinegética que se impugna «atendiendo a unos fines y objetivos que forman parte de una orientación de política general, cuya determinación corresponde al órgano legislativo, y que no constituyen la respuesta ad casum de determinadas resoluciones judiciales».

Por tanto, al descartar el TC que la Ley 9/2019, de modificación de la Ley 4/1996, de caza en la Comunidad Autónoma de Castilla y León, tenga la naturaleza de ley singular, queda rechazada la tacha del Defensor del Pueblo 
sin necesidad de examinar si los concretos preceptos impugnados de esa ley cumplen las exigencias que, de acuerdo con la doctrina constitucional, deben respetar este tipo de leyes para ser conformes con la Constitución.

Los razonamientos y conclusiones de la STC 148/2020, FJ 5, se trasladan por el TC a la STC 149/2020, FJ 3, para rechazar que la Ley 9/2019, de modificación de la Ley 4/1996, de caza en la Comunidad Autónoma de Castilla y León, constituya un supuesto de ley singular, como entendía también el órgano judicial promotor de la cuestión desestimada por esta sentencia.

2. Sobre la incidencia que puedan tener las infracciones del procedimiento legislativo en la validez de la ley se pronuncian en el período que nos ocupa la ya citada STC 148/2020 (Pleno), de 22 de octubre, y la STC 172/2020 (Pleno), de 19 de noviembre.

En la STC 148/2020, FJ 4, se examina la alegada, bien que de manera imprecisa, vulneración del procedimiento legislativo seguido para la aprobación de la Ley 9/2019, de modificación de la Ley 4/1996, de caza en la Comunidad Autónoma de Castilla y León; vulneración fundada en la insuficiencia de la documentación aportada en su tramitación, es decir, en la ausencia de unos elementos de juicio (informes y estudios técnicos y jurídicos) que avalaran el cumplimiento de las reglas de protección medioambiental, según el Defensor del Pueblo. El TC recuerda su doctrina acerca del control constitucional de las infracciones del procedimiento legislativo, conforme a la cual lo primero que ha de examinarse es si se ha producido vulneración de la normativa reguladora de la elaboración de las leyes para valorar a continuación si esa vulneración, en caso de haber existido, pudo tener relevancia para la formación de la voluntad legisladora, teniendo en cuenta que el vicio procedimental solo adquiere dimensión constitucional si es susceptible de afectar de forma sustancial al proceso de formación de la voluntad de la Cámara legislativa, incidiendo, en consecuencia, en el ejercicio de la función representativa inherente al Estatuto del parlamentario. En el caso de los parlamentos autonómicos esa valoración requiere atender al bloque de la constitucionalidad aplicable, constituido por las previsiones del Estatuto de Autonomía y el Reglamento de la Cámara de que se trate.

Partiendo de este canon de control de constitucionalidad, la STC 148/2020, FJ 4, descarta que se haya producido en la aprobación de la Ley 9/2019, de modificación de la Ley 4/1996, de caza en la Comunidad Autónoma de Castilla y León, la vulneración del procedimiento legislativo que alega el Defensor del Pueblo, pues la ley ha sido aprobada de conformidad con el procedimiento previsto en el bloque de constitucionalidad aplicable, que se 
contiene en el art. 24.1 del estatuto de autonomía de esa comunidad autónoma en relación con los arts. 121 y 122 del Reglamento de las Cortes de Castilla y León; sin que el recurrente mencione tampoco ninguna norma de ese estatuto o del Reglamento de la Cámara de la que pudiera deducirse la obligatoriedad de aportar los pretendidos informes técnicos y jurídicos para avalar el cumplimiento de las reglas de protección medioambiental.

Por su parte, la STC 172/2020, que resuelve el recurso de inconstitucionalidad interpuesto por más de cincuenta diputados contra diversos preceptos de la Ley Orgánica 4/2015, de 30 de marzo, de protección de la seguridad ciudadana, descarta, a su vez, la alegada vulneración del procedimiento legislativo seguido para la aprobación de esta ley, en lo que atañe a la impugnación del régimen especial para Ceuta y Melilla de rechazo en frontera de los extranjeros que intenten entrar ilegalmente, establecido por la disposición final primera de la Ley Orgánica 4/2015, que introduce una disposición adicional décima en la Ley Orgánica 4/2000, de 11 de enero, sobre derechos y libertades de los extranjeros en España y su integración social.

Los diputados recurrentes sostenían que esta regulación, introducida en la tramitación parlamentaria por vía de enmienda a través del informe de la ponencia, no guarda conexión alguna con la Ley Orgánica sobre derechos y libertades de los extranjeros en España, lo que vulneraría el art. 23.2 CE por incurrir en fraude del procedimiento parlamentario. La STC 172/2020, FJ $8 . \mathrm{B}$, rechaza que se haya producido esa pretendida infracción constitucional. Recuerda el TC su reiterada doctrina conforme a la cual, desde el punto de vista de la legalidad parlamentaria, «el ejercicio del derecho de enmienda al articulado debe respetar una conexión mínima de homogeneidad con el texto enmendado, so pena de afectar tanto al derecho del autor de la iniciativa (art. $87 \mathrm{CE}$ ), como al carácter instrumental del procedimiento legislativo (art. 66.2 CE) y, en consecuencia, a la función y fines asignados al ejercicio de la potestad legislativa por las Cámaras». Para determinar si concurre tal conexión material u homogeneidad mínima los órganos de gobierno de las Cámaras cuentan con un amplio margen de apreciación, de modo que «solo cuando sea evidente y manifiesto que no existe tal conexión deberá rechazarse la enmienda, puesto que, en tal caso, se pervertiría la auténtica naturaleza del derecho de enmienda, ya que habría pasado a convertirse en una nueva iniciativa legislativa». Aplicando al caso esta doctrina, concluye el TC que no se puede considerar que el objeto de la enmienda no cumpla con el principio de conexión mínima de homogeneidad:

El precepto impugnado aborda la regulación de un régimen especial en materia de extranjería para hacer frente a la situación de riesgo que se produce en los 
perímetros fronterizos de Ceuta y Melilla — frontera exterior de la Unión Europea- por la presión migratoria. Es por ello que esta cuestión no se puede calificar de totalmente extraña a la seguridad ciudadana, integrante de la más amplia materia de la seguridad pública; sin que se pretenda, en ningún caso, asociar necesariamente el fenómeno de la inmigración de personas extranjeras con un incremento de la inseguridad ciudadana.

3. En relación con la fuerza vinculante de los convenios colectivos y su posición en el sistema de fuentes se pronuncia el ATC 172/2020 (Pleno), de 15 de diciembre, que inadmite la cuestión de inconstitucionalidad planteada por un juzgado de lo social respecto de un precepto de una ley del Parlamento de Galicia de medidas temporales en determinadas materias de empleo público, que suspende la aplicación de una norma del convenio colectivo para el personal laboral de la Xunta de Galicia que regula el régimen de descanso en domingos y festivos de ese personal.

El órgano judicial promotor de la cuestión entendía que la norma legal cuestionada, al suspender la aplicación de un precepto del convenio colectivo válidamente aprobado de conformidad con la legislación laboral, invadía la competencia exclusiva del Estado en materia de legislación laboral (art. 149.1.7 CE) y vulneraba la garantía de la negociación colectiva y la fuerza vinculante de los convenios colectivos (art. 37.1 CE). En relación con esta última tacha, que es la que ahora interesa, el TC la rechaza, por considerarla notoriamente infundada, a la vista de la consolidada doctrina constitucional conforme a la cual la negociación colectiva de los empleados públicos no es límite ni condición para la potestad legislativa del Parlamento, solo limitado en derecho por la Constitución y por el control estrictamente jurídico derivado de ella que el TC tiene encomendado. Del art. 37.1 CE no deriva una supuesta intangibilidad o inalterabilidad del convenio colectivo frente a la ley, incluso aunque se trate de una norma legal sobrevenida. En suma, «en virtud del principio de jerarquía normativa, es el convenio colectivo el que debe respetar y someterse no solo a la ley formal, sino, más genéricamente, a las normas de mayor rango jerárquico y no al contrario» (ATC 172/2020, FJ 2, citando reiterada doctrina constitucional al respecto) ${ }^{16}$.

\section{ORGANIZACIÓN TERRITORIAL DEL ESTADO}

1. Durante el tercer cuatrimestre de 2020 el número de pronunciamientos del TC en materia de organización territorial ha sido relativamente

16 Herminio Losada González. 
bajo. Entre los pronunciamientos competenciales que cabe destacar por las novedades doctrinales que en estos se plantean estarían los siguientes.

2. La STC 134/2020 (Pleno), de 23 de septiembre ${ }^{17}$, resuelve el recurso de inconstitucionalidad interpuesto por el Gobierno Vasco contra determinadas disposiciones del Real Decreto Ley 15/2018, de 5 de octubre, de medidas urgentes para la transición energética y la protección de los consumidores.

La norma estatal regula una pluralidad de materias vinculadas con la energía y con la protección de los consumidores vulnerables, pero en el presente proceso se impugnan únicamente aquellos preceptos de la norma estatal mediante los que se establece y regula el denominado bono social térmico. Se trata de una nueva ayuda para aquellos consumidores vulnerables que estén acogidos al bono social de electricidad y que ahora recibirán a lo largo del invierno un bono para sufragar otros usos energéticos del hogar distintos de la electricidad como combustibles para calefacción, agua caliente sanitaria o cocina. La cuantía del bono se modulará por la zona climática en la que se encuentre la vivienda y dependerá del grado de vulnerabilidad del hogar. No se trata de ayudas otorgadas en régimen de concurrencia competitiva, pues ni siquiera es necesaria la previa solicitud del beneficiario, ya que basta con el cumplimiento de los requisitos para tener derecho a la ayuda.

La regulación del bono por parte del Estado parece querer asumir la doctrina del TC en materia de ayudas y subvenciones, pues reconoce explícitamente que la gestión y el pago del bono social térmico deben corresponder a las comunidades autónomas y, por ello, prevé, en general, un sistema descentralizado de gestión de este.

En efecto, de acuerdo con la exposición de motivos de la norma impugnada, puesto que el bono social térmico se debe encuadrar «en materia de asistencia social, competencia que ha sido asumida estatutariamente por todas las CC. AA., corresponde su gestión por ello a las CC. AA., sin perjuicio de la competencia del legislador estatal para establecer los criterios y metodología para el reparto y cálculo de la ayuda unitaria».

Sin embargo, la asunción de la doctrina del TC en materia de ayudas no acaba de ser plena, pues para el ejercicio 2019 la norma impugnada, en su disposición adicional novena, reserva de manera excepcional la gestión centralizada de bono social térmico al Ministerio para la Transición Ecológica con fundamento en el «calendario en que nos hallamos y la necesidad de que el bono social térmico llegue a sus destinatarios en invierno» de ese año.

17 Véase, supra, p. 222. 
Como no podía ser de otra manera, tal gestión centralizada para el año 2019 es declarada inconstitucional y nula por la STC 134/2020, si bien al haberse producido ya el reparto de los fondos la propia sentencia modula los efectos de tal declaración para que tenga efectos puramente declarativos.

Sobre el resto de preceptos impugnados, la STC 134/2020 no aprecia causa de inconstitucionalidad en cuanto a los requisitos que han de cumplir los beneficiarios de las ayudas o a los criterios a partir de los cuales se determina la cuantía de las ayudas, que son para la STC 134/2020 condiciones que el Estado puede fijar de acuerdo con una doctrina reiterada desde la STC 178/2011, de 8 de noviembre. Esta última sentencia, recordemos, supuso un verdadero overruling, no explicitado, de la STC 13/1992, de 6 de febrero, pues el TC considera a partir de entonces que en aquellos supuestos en los que el Estado no tiene título competencial alguno, genérico o específico, sobre una materia - es decir, cuando nos encontramos en el primer supuesto recogido en el fundamento jurídico 8.a de la STC 13/1992-, el Estado tiene, no obstante, incluida en su esfera de decisión la regulación de los aspectos centrales del régimen subvencional —objeto y finalidad de las ayudas, modalidad técnica de estas, beneficiarios y requisitos esenciales de acceso-, mientras que la competencia autonómica se reduce a lo atinente a su gestión, esto es, la tramitación, resolución y pago de las subvenciones, así como la regulación del procedimiento correspondiente a todos estos aspectos.

No obstante lo anterior, la STC 134/2020 declara la inconstitucionalidad y nulidad tanto de la previsión de que la ayuda haya de abonarse mediante la concesión de un pago único anual como la previsión de que se deba abonar «durante el primer trimestre del año». Para la STC 134/2020, no se trata de aspectos centrales del régimen de la ayuda. Aun siendo conveniente que, tal como dice el preámbulo, se reciba la ayuda a lo largo del invierno, no se puede obviar que estamos en un ámbito en el que la competencia estatal se limita a regular los aspectos centrales de la ayuda. Considera la STC 134/2020 que no es posible apreciar una relación directa con la finalidad que la ayuda persigue que justifique que esta previsión pudiera ser fijada por el Estado, en tanto que las necesidades que atender son las de gasto de energía destinada a calefacción, agua caliente sanitaria o cocina, y estas pueden ser más acuciantes en unos u otros períodos del ańo, pero, al menos en dos casos, se extienden, obviamente, a todo el año. Además, la STC 134/2020 subraya que la regulación estatal no incluye ningún mecanismo destinado a asegurar que la ayuda se destine efectivamente a la finalidad para la que fue concedida, lo que reduce la necesidad de que el Estado, al regular los criterios de reparto, sea el que determine un aspecto que no es central en el régimen de la subvención, sino que está más directamente 
relacionado con la gestión autonómica, como es determinar el momento o la periodicidad del pago.

La STC 134/2020 igualmente considera inconstitucional y nulo un inciso del art. 11, relativo a las obligaciones de los comercializadores de referencia, al considerar que se vincula directamente a tareas de gestión que exceden de las facultades estatales en relación con esta ayuda y se incluyen en las competencias autonómicas para gestionarla.

Hay un último aspecto de la STC 134/2011 que merece ser comentado. Se trata de cómo aborda el TC la impugnación de la disposición final tercera, que es en la que se recogen los títulos competenciales que darían amparo al Real Decreto Ley 15/2018.

Yerra la sentencia al considerar que en tal disposición se estarían mencionando los títulos competenciales que darían amparo a la regulación del bono social térmico, pues se debe interpretar la disposición a la luz de la exposición de motivos de la propia norma.

En efecto, de acuerdo con la exposición de motivos, el real decreto ley, que recordemos que regula una pluralidad de medidas en materia energética, se dicta en virtud de las competencias atribuidas al Estado en materia de bases y coordinación de la planificación general de la actividad económica y bases del régimen minero y energético por el art. 149.1.13. ${ }^{\mathrm{a}}$ y $25 .^{\mathrm{a}} \mathrm{CE}$.

Sin embargo, en lo que se refiere específicamente al bono social térmico, la exposición de motivos explícitamente subraya que "ha sido dictado al amparo de la soberanía financiera que tiene el Estado para asignar fondos públicos a una u otra finalidades (por todas, y como más reciente, STC 88/2018, de 19 de julio, F.J.4.a)», pues, tal y como esa misma exposición de motivos reconoce, el bono social térmico es una ayuda que cabe encuadrar «en materia de asistencia social, competencia que ha sido asumida estatutariamente por todas las CC. AA.».

Es decir, la disposición final tercera, que la STC 134/2020 acaba declarando inconstitucional en el sentido de que los títulos competenciales que allí se citan no amparan a la regulación objeto del presente proceso, no recoge los títulos competenciales en los que se funda la regulación del bono social térmico, pues, al ser una regulación referida a la asistencia social, el Estado no tiene título. Así lo reconoce explícitamente la exposición de motivos.

Ello, claro, no quiere decir que el Estado no pueda regular tales ayudas, pues el propio TC ha considerado que el poder de gasto del Estado o de autorización presupuestaria, manifestación del ejercicio de la potestad legislativa atribuida a las Cortes Generales (arts. 66.2 y $134 \mathrm{CE}$ ), no se define por conexión con el reparto competencial de materias que la Constitución establece (arts. 148 y $149 \mathrm{CE}$ ), al contrario de lo que acontece con la autonomía 
financiera de las comunidades autónomas, que se vincula al desarrollo y ejecución de las competencias que, de acuerdo con la Constitución, les atribuyan los respectivos estatutos y las leyes (art. 156.1 CE y art. 1.1 de la LOFCA) (por todas en la paradigmática STC 13/1992, FJ 7).

Por consiguiente, el Estado siempre podrá, en uso de su soberanía financiera (de gasto, en este caso), asignar fondos públicos a unas finalidades u otras, pues existen otros preceptos constitucionales (y singularmente los del capítulo III del título I y el art. 9.2 CE) que legitiman la capacidad del Estado para disponer de su presupuesto en la acción social o económica. El Estado tiene la capacidad, por tanto, sin necesidad de tener que fundar aquella en ninguno de los apartados del art. 149.1 CE, para poner su poder de gasto al servicio de una política de asistencia social, sin perjuicio de que corresponda a la comunidad autónoma la competencia exclusiva en tal materia. Así se explicaba precisamente en la exposición de motivos de la norma impugnada.

3. La STC 135/2020 (Pleno), de 23 de septiembre ${ }^{18}$, resuelve el conflicto positivo de competencia promovido por el Gobierno de la Nación contra el Acuerdo Gov/90/2019, de 25 de junio, del Gobierno de la Generalitat de Cataluña, por el que se aprueba el plan estratégico de acción exterior y de relaciones con la Unión Europea 2019-2022 y se acuerda su envío al Parlamento de Cataluña.

El conflicto se articula por el Gobierno en torno a tres motivos de impugnación: i) el incumplimiento, en el ámbito de la acción exterior, de los principios de lealtad institucional, colaboración y coordinación que deben regir las relaciones entre el Estado y las comunidades autónomas; ii) la vulneración de las competencias estatales en materia de relaciones internacionales del art. 149.1.3 CE, y iii) la infracción de otras competencias estatales más específicas, en la que incurrirían puntos concretos del plan.

La cuestión más novedosa tiene que ver con el primer motivo, pues la impugnación del Gobierno se propone incitar al TC a que desarrolle y construya una doctrina más depurada en relación con el principio de lealtad constitucional. Doctrina que debería permitir al TC ir más allá de aquellas apelaciones genéricas a la lealtad recogidas en su jurisprudencia anterior, pues el Gobierno le propone ahora al TC que de aquel principio se extraigan deberes concretos que puedan tener como consecuencia en caso de ser incumplidos la declaración de inconstitucionalidad y nulidad del acto o disposición impugnado.

18 Véanse, supra, p. 226. 
Bajo este primer motivo se solicita la nulidad de todo el plan en la medida en que está concebido íntegramente desde una resuelta posición de ajenidad a la Constitución, a la política exterior y los principios contenidos en la Ley 2/2014. En efecto, denuncia el Gobierno como la ausencia de menciones en el plan autonómico a aquellos instrumentos normativos estatales que tienen implicaciones en la acción exterior que puede desarrollar la comunidad autónoma, la ausencia de menciones a los otros sujetos de la acción exterior del Estado y la ausencia de menciones a la necesidad de coordinar la acción exterior de Cataluña con la política exterior española y su acción exterior, así como con las estrategias y planes relevantes, vulnerarían el principio de lealtad del cual cabría derivar - en un ámbito tan peculiar como el de la acción exterior de un Estado donde cómo se presente uno, o sus subdivisiones territoriales, ante el resto de actores internacionales no es irrelevante- una concreta obligación de que se hiciese mención a todo ello en el propio plan autonómico.

El objeto de la impugnación es, en realidad, la omisión de toda referencia explícita a la competencia estatal en materia de relaciones internacionales. De la ausencia de referencias a las normas estatales y de un determinado uso del lenguaje pretende el Gobierno derivar la vulneración del principio de lealtad y de las competencias estatales por menoscabo o por perturbación, al estimar que la ausencia de una referencia explícita a la competencia estatal supone poner en entredicho el ejercicio de dicha competencia.

Sin embargo, la STC 135/2020 no considera procedente extraer concretos deberes u obligaciones del principio de lealtad, como en alguna ocasión habría hecho, por ejemplo, el Tribunal Constitucional Federal alemán, y desestima el conflicto en este punto con fundamento en la clásica doctrina ya recogida en la STC 228/2016, de 22 de diciembre, y que consideró que la ausencia de una reserva expresa de las competencias del Estado sobre política exterior $e x$ art. 149.1.3 CE no determina la inconstitucionalidad del plan. Para el TC del simple silencio respecto de las competencias y potestades estatales no se infiere con carácter ineludible que no deban ser atendidas, ni su efectividad depende del expreso reconocimiento autonómico.

No considera la STC 135/2020 relevante el contexto en el que se adopta la disposición impugnada, que había sido aportado por el demandante para tratar de mostrar cómo toda la acción exterior autonómica estaba girando en torno a la denominada internacionalización del procés y a la deslegitimación del Estado. En efecto, el Gobierno trata de justificar la necesidad de que en el plan se hagan explícitamente las menciones a las que nos hemos referido, mostrando como, tras lo acaecido en el otońo de 2017, la acción exterior de la comunidad autónoma se venía desarrollando con la finalidad de producir el 
desprestigio de la imagen internacional de España. Sin embargo, para el TC el contexto no debe ser tomado en cuenta, pues se correría el riesgo de llevar el debate jurídico al campo de las «intencionalidades políticas».

Ciertamente tal doctrina se estableció antes de los sucesos de octubre de 2017 y cabría plantearse hasta qué punto, y cuando del principio de lealtad se trata, cabe que el TC siga manteniendo, de manera algo naif, que solo puede ser objeto de debate jurídico constitucional el tenor literal de las normas.

Excluida la primera tacha de inconstitucionalidad procede a continuación la STC 135/2020 a examinar el segundo motivo, para lo cual analiza los concretos contenidos del plan impugnado, a fin de determinar si se trata de acciones con proyección exterior para la promoción de sus intereses que se deriven directamente de las competencias de la Generalitat de Cataluña (art. 193.2 EAC), y no perturban ni interfieren en la competencia estatal del art. 149.1.3 CE. Recuerda el TC que la acción exterior autonómica no puede significar en ningún caso la consideración de Cataluña como un sujeto de derecho internacional, cualidad de la que como ente territorial carece. Esa acción exterior debe ejercerse siempre con respeto a la competencia del Estado en materia de relaciones exteriores (art. 149.1.3 CE).

Tal examen se concreta en la declaración de que determinados aspectos de dichas actuaciones no se ajustan al orden constitucional de distribución de competencias y otros lo hacen solamente si son interpretados de conformidad con la STC 135/2020.

Así ocurre, a mero título de ejemplo, y respecto a lo primero, en relación con aquellos puntos del plan sobre "consolidación y fortalecimiento de vínculos con el cuerpo diplomático y consular», «diseño de una estrategia para reforzar y consolidar las relaciones con el cuerpo diplomático y consular de acuerdo con los objetivos estratégicos de la acción exterior del Gobierno de Cataluña» y "mantenimiento de relaciones estrechas, regulares y fluidas con el conjunto del cuerpo consular establecido en Barcelona, dado que la capital catalana está en las primeras posiciones de las ciudades no capital de Estado con más representación diplomática en todo el mundo», que son declarados inconstitucionales y nulos por contravenir la reserva competencial estatal del art. 149.1.3 CE en relación con el ius legationis. Igualmente, inconstitucional y nulo es el punto referido a la «puesta en marcha del Consejo de Diplomacia Pública de Cataluña», puesto que, según la STC 135/2020, induce a confusión en el ámbito de las relaciones internacionales acerca del verdadero contenido y alcance de esas actividades del referido Consejo y su relación con la política exterior espańola.

A continuación, procede el TC a examinar el tercer motivo a través del análisis de aquellos otros puntos del plan a los que el abogado del Estado 
imputa la vulneración de determinadas competencias del Estado distintas de la del art. 149.1.3 CE. Así se trata de la contravención de las competencias estatales atribuidas en los apdos. 4, 13, 20, 21, 23, 24, 25 y 29 del art. 149.1 CE.

De nuevo a mero título de ejemplo, se declara la inconstitucionalidad y nulidad de puntos como los referidos a la «internacionalización y ordenación del sistema portuario catalán» y a la «internacionalización de los aeropuertos de Cataluña», pues el art. 149.1.20 CE atribuye al Estado la competencia exclusiva sobre puertos y aeropuertos de interés general, lo que impide efectivamente a la Generalitat disponer sobre ellos.

La STC 135/2020 cuenta con un voto particular conjunto formulado por el magistrado Xiol Ríos y la magistrada Balaguer Callejón que sostiene que la planificación en materia de acción exterior no afectaría a la esfera jurídica de los administrados, pues tiene efectos fundamentalmente ad intra, esto es, de coordinación administrativa, de buen funcionamiento y de gestión de los servicios destinados a desplegar acciones fuera del territorio de la comunidad autónoma, incluso fuera del Estado en que se integra la comunidad autónoma. Ello supone para los firmantes del voto que aquella planificación debería ser evaluada, desde el punto de vista de su examen de constitucionalidad, con menor intensidad que, por ejemplo, la planificación en materia de ordenación y gestión del espacio y del medio ambiente, por ejemplo, que tiene unos efectos ad extra más claros.

4. La STC 148/2020 (Pleno), de 22 de octubre ${ }^{19}$, resuelve el recurso de inconstitucionalidad interpuesto por el Defensor del Pueblo en relación con diversos preceptos de la Ley 9/2019, de 28 de marzo, de modificación de la Ley 4/1996, de 12 de julio, de caza en la Comunidad Autónoma de Castilla y León.

El Defensor del Pueblo fundamenta su impugnación en dos motivos diferenciados: por un lado, considera que los preceptos impugnados vulneran la legislación básica estatal en materia de medio ambiente, en concreto, lo señalado en los arts. 54.1 y 5, 61.1 y 65 de la Ley 42/2007, de 13 de diciembre, de patrimonio natural y de la biodiversidad, y, en consecuencia, infringen lo señalado en los arts. 45 y 149.1.23 CE; por otro, afirma que los preceptos de la norma autonómica tienen la naturaleza de ley singular, y han sido aprobados con la única finalidad de eludir el cumplimiento y dejar sin efecto determinadas resoluciones judiciales, por lo que vulneran los arts. 9.3, y 24.1 CE.

19 Véanse, supra, pp. 237-239. 
En el presente apartado de la crónica referido a la organización territorial examinaremos únicamente el primer motivo, dejando el segundo para otro apartado de esta.

La regulación controvertida ha sido dictada por la comunidad autónoma en ejercicio de su competencia en materia de «caza y explotaciones cinegéticas» que le reconoce el art. 70.1.17 del Estatuto de Autonomía de Castilla y León. Ciertamente, sobre esta competencia autonómica incide la competencia que el art. 149.1.23 CE reserva al Estado para dictar la legislación básica en materia de protección del medio ambiente.

En efecto, admite la STC 148/2020 que la legislación básica medioambiental que actuaría como parámetro de contraste de la norma autonómica se contendría en la Ley 42/2007, de 13 de diciembre, del patrimonio natural y de la biodiversidad, en la que se transponen al derecho español la Directiva 79/409/CEE del Consejo, de 2 de abril de 1979, relativa a la conservación de las aves silvestres, y la Directiva 92/43/CEE del Consejo, de 21 de mayo de 1992, relativa a la conservación de los hábitats naturales y de la fauna y flora silvestres, debidamente actualizadas.

Más concretamente el precepto de la Ley 42/2007 que se considera normativa básica de contraste sería el art. 54, en el que se establece la obligación de la Administración General del Estado y de las comunidades autónomas de adoptar las medidas necesarias para garantizar la biodiversidad que vive en estado silvestre y de contemplar regímenes específicos de protección para aquellas especies silvestres cuya situación así lo requiera.

Precisamente el Defensor del Pueblo alega que la ley autonómica, al optar por que sea la propia Ley 9/2019 (en los términos previstos en el anexo I) la que enumere las especies animales susceptibles de aprovechamiento cinegético, habría sido aprobada sin los exigibles informes y estudios científicos y técnicos que respalden su adecuación al deber básico de conservación de las especies afectadas y que acrediten que este deber no se verá disminuido por la práctica de la caza. Más concretamente considera que el criterio que se afirma haber utilizado por la norma autonómica para la declaración como cinegéticas de determinadas especies referido a que, de acuerdo con sus niveles poblacionales, su distribución geográfica y su índice de reproductividad, puedan aquellas soportar una extracción ordenada de ejemplares no resulta probado a través de informes y estudios científicos y técnicos.

Sin embargo, la STC 148/2020 rechaza la contravención de las bases en los términos expresados por el recurrente, pues considera que se ha formulado la controversia con un carácter hipotético o preventivo, limitándose a afirmar que no resulta probada la conformidad de los preceptos impugnados con la legislación básica medioambiental, pero sin hacer mención en el texto de la 
demanda a cuáles han de ser estos informes omitidos; es decir, no se individualiza la fuente normativa que los contemplaría como exigibles, ni se hace mención a las específicas razones de carácter sustantivo de las que derivaría que la declaración como cinegéticas de determinadas especies por la norma autonómica es susceptible de atentar contra el deber general de protección de la fauna silvestre establecido en la norma básica.

Por tanto, la STC 148/2020 desestima la impugnación por motivos competenciales por carecer la demanda de una carga argumental mínima.

La STC 148/2020 tiene interés por otra cuestión, que, no obstante, puede considerarse mal enfocada, y es que el TC parece en un momento de la sentencia reconducir la alegación de inconstitucionalidad mediata a una vulneración del procedimiento legislativo seguido para la aprobación de la ley autonómica; vulneración que se consideraría proveniente de la insuficiencia de la documentación aportada en su tramitación, es decir, en la ausencia de unos elementos de juicio (informes y estudios técnicos y jurídicos) que avalaran el cumplimiento de las reglas de protección medioambiental. Sin embargo, la cuestión planteada nada tiene que ver con un vicio del procedimiento legislativo, sino con la vulneración, en su caso, de la normativa básica estatal de protección ambiental.

5. La Sentencia 152/2020 (Pleno), de 22 de octubre, aborda el conflicto positivo de competencia planteado por la Generalitat de Cataluña respecto del escrito de 3 de marzo de 2020 de la directora de Competencia de la Comisión Nacional de los Mercados y la Competencia, por el que se requiere a la Autoridad Catalana de la Competencia la remisión del expediente "Campaña de Consumo Estratégico» con fundamento en que el efecto supraautonómico de la campaña implicaría que la instrucción y resolución del procedimiento de defensa de la competencia correspondan a la CNMC, en lugar de a la autoridad catalana.

La STC 152/2020 subraya que la cuestión debatida en el presente conflicto se enmarca en el ámbito de la defensa de la competencia, materia que ha podido ser regulada por el Estado en ejercicio de su competencia sobre «bases y coordinación de la planificación general de la actividad económica» (art. 149.1.13 CE). De acuerdo con la jurisprudencia constitucional plasmada desde la STC 208/1999, de 11 de diciembre, puesto que nos hallamos ante un elemento definitorio del mercado, no solo la normación, sino todas las actividades ejecutivas que determinen la configuración real del mercado único de ámbito nacional habrán de atribuirse al Estado, al que corresponderán, por lo tanto, las actuaciones ejecutivas en relación con aquellas prácticas que puedan alterar la libre competencia en un ámbito supracomunitario o en el conjunto 
del mercado nacional. Sin embargo, corresponderán a las comunidades autónomas «aquellas actuaciones ejecutivas que hayan de realizarse en su territorio y que no afecten al mercado supracomunitario».

Una vez expuesto el parámetro aplicable, la STC 152/2020 procede a aplicarlo al supuesto controvertido examinando si la campaña «Consumo estratégico" puede alterar la libre competencia en un ámbito supraautonómico o en el conjunto del mercado nacional.

Señala la STC 152/2020 que el objetivo declarado de la campańa es encauzar las opciones de los consumidores catalanes, tanto privados como públicos (las mociones impulsadas en varios ayuntamientos iban encaminadas a que estos también contrataran con proveedores "estratégicos» catalanes), en favor de empresas ubicadas en Cataluña y que se encontraran alineadas con los postulados políticos de la ANC, entre los que destaca «la constitución de un estado catalán propio, independiente, de derecho, social y democrático» (art. 2.1.a de sus estatutos).

Este llamamiento para contratar con proveedores catalanes afines al ideario independentista, en perjuicio del resto, tiende a crear, "como aspiración ideal, un mercado propio catalán». Pues bien, ante tales rasgos de la campaña, la STC 152/2020 recuerda que la razón de que la STC 208/1999, FJ 6, atribuyera ciertas competencias ejecutivas al Estado para aplicar la Ley de defensa de la competencia fue garantizar «la configuración real del mercado único de ámbito nacional», es decir, preservar un mercado nacional y evitar su fragmentación, pues un mercado compartimentado equivale a la quiebra del conjunto como tal.

Para la STC 152/2020, la importancia de preservar la libre circulación en el territorio espańol (art. 139.2 CE) y evitar la «fragmentación del mercado» se plasma en el art. 1.2.b de la Ley 1/2002, de 21 de febrero, de Coordinación de las Competencias del Estado y las Comunidades Autónomas en materia de Defensa de la Competencia - cuya constitucionalidad no pone en duda la Generalitat-, precepto que, entre los criterios para valorar si una conducta «altera o puede alterar la libre competencia en un ámbito supraautonómico o en el conjunto del mercado nacional», incluye el de que "obstaculice la libre circulación de bienes» o suponga «la compartimentación de los mercados».

En suma, la STC 152/2020 concluye considerando que la pretensión de crear mercados separados, en el caso que nos concierne, un mercado catalán propio y desvinculado del español, debe ser analizada por el organismo responsable de garantizar la competencia en el mercado único afectado, en este caso, la CNMC, lo que le lleva a desestimar la impugnación planteada.

Resta destacar cómo el TC reitera y perfila la novedosa construcción que inició en la STC 79/2017, de 22 de junio, FJ 2, en relación con el mercado 
nacional único. Así, tras recordar los rasgos característicos de un mercado único — ser un espacio donde se encuentren garantizadas la libre circulación de personas y bienes, y ser un espacio donde las condiciones esenciales de ejercicio de la actividad económica sean iguales-, subraya cómo tales rasgos se promueven, bien a través de lo que denomina garantías estructurales - aquellos preceptos del título VIII de la Constitución que suponen un límite en sí a la diversidad regulatoria que puedan introducir los legisladores autonómicos en el ejercicio de sus competencias-, bien a través de las garantías dinámicas -aquellos títulos competenciales transversales que permiten que el Estado pueda intervenir normativamente a fin de garantizar esa unidad-.

La consecuencia fundamental que extrae la STC 152/2020 de tal construcción es que corresponde al Estado, al ejercer sus competencias transversales, la decisión de promover los rasgos del mercado único, "pues debe recordarse que tales competencias no suponen, en realidad, una reserva al Estado de ámbitos materiales exclusivos y excluyentes, sino que suponen habilitaciones a aquel para la consecución de determinados fines, incluso aunque ello suponga, caso de efectivamente ejercerse, afectar a ámbitos materiales atribuidos a las comunidades autónomas».

En definitiva, para el TC el grado de unidad del mercado nacional no se encontraría impuesto por la Constitución, sino que dependería de una decisión política del legislador estatal a través del ejercicio efectivo sus competencias transversales.

6. Cabe finalmente subrayar que durante el tercer cuatrimestre de 2020 la conflictividad por motivos competenciales ante el TC se ha mantenido relativamente baja.

El Gobierno de la Nación ha planteado un conflicto positivo de competencias contra una serie de preceptos del Decreto 87/2020, de 9 de diciembre, del presidente de la Comunidad Autónoma de Canarias, por el que se establece el cierre perimetral de la comunidad autónoma de Canarias, en aplicación del Real Decreto 926/2020, de 25 de octubre, por el que se declara el estado de alarma, para contener la propagación de infecciones causadas por el SARS-COV-2. El conflicto de competencia se fundamenta en que las disposiciones impugnadas vulneran la competencia exclusiva del Estado en materia de sanidad exterior (art. 149.1.16 CE).

Asimismo, el Gobierno ha planteado recurso de inconstitucionalidad frente a la disposición transitoria décima, apdo. segundo, de la Ley 7/2019, de 27 de junio, de quinta modificación de la Ley de Policía del País Vasco, por vulneración de la competencia del Estado para establecer las bases del régimen estatutario de los funcionarios públicos (art. 149.1.18 CE). 
Por su parte, el Consejo de Gobierno de la comunidad autónoma de Andalucía ha interpuesto un conflicto positivo de competencia contra un precepto del Real Decreto 498/20, de 28 de abril, por el que se desarrolla la estructura orgánica básica del Ministerio de Educación y Formación Profesional, por vulnerar la competencia autonómica ejecutiva en materia de legislación laboral.

No obstante lo anterior, algunas cuestiones competenciales se siguen planteando ante el TC a través de las impugnaciones frente a normas con rango de ley autonómicas que han presentado diputados y senadores de los diversos partidos políticos con legitimación suficiente para ello.

Así, en el cuatrimestre objeto de análisis en la presente crónica, el Grupo Parlamentario Vox impugnó diversos preceptos de la Ley 3/2020, de 27 de julio, de recuperación y protección del Mar Menor, de la comunidad autónoma de la Región de Murcia, por considerar, entre otros motivos, que vulneraba las competencias estatales recogidas en el art. 149.1, apdos. 1, 8, 13,22 y 23.

Senadores del Grupo Parlamentario Socialista interpusieron recurso de inconstitucionalidad contra el Decreto Ley 2/2020, de 9 de marzo, de mejora y simplificación de la regulación para el fomento de la actividad productiva de Andalucía. Entre los diversos motivos de impugnación se encontraba la vulneración de la competencia estatal en materia de patrimonio histórico.

Asimismo, senadores del Grupo Parlamentario Socialista interpusieron recurso de inconstitucionalidad contra el Decreto Ley 6/2020, de 2 de julio, de medidas urgentes para incentivar las medidas de recuperación económica y social en el ámbito local, aprobado por el Gobierno de la Junta de Castilla y León. Entre los motivos de impugnación está la vulneración de la previsión del art. 25.4 del Estatuto de Autonomía de Castilla y León que prohíbe el uso del decreto ley "para la regulación de materias para las que el presente Estatuto exija expresamente la aprobación de una ley de Cortes», siendo una de ellas la participación de las entidades locales en los ingresos de la comunidad.

Igualmente, diputados del Grupo Parlamentario Popular del Congreso han interpuesto recurso de inconstitucionalidad frente al art. 5 de la Ley del Parlamento de Cataluña 5/2020, de 29 de abril, de medidas fiscales, financieras, administrativas y del sector público y de creación del impuesto sobre las instalaciones que inciden en el medio ambiente, por vulneración de los arts. 157.2 CE y 6.2 y 9.c) LOFCA.

Diputados del Grupo Parlamentario Popular del Congreso han impugnado, asimismo, el Decreto Ley 6/2020, de 5 de junio, del Consell, para la ampliación de vivienda pública en la Comunitat Valenciana mediante los derechos de tanteo y retracto, por vulneración de las competencias del Estado 
sobre legislación civil, legislación mercantil, legislación procesal, expropiación y la competencia relativa a la fijación de las condiciones básicas para el ejercicio de los derechos constitucionales (recogidas en los apdos. 1, 6, 8 y 18 del art. 149.1 CE).

Finalmente, diputados del Grupo Parlamentario Popular del Congreso han impugnado diversos preceptos de la Ley de Cataluña 11/2020, de 18 de septiembre, de medidas urgentes en materia de contención de rentas en los contratos de arrendamiento de vivienda, por, entre otros motivos, vulnerar las competencias del Estado sobre la fijación de las bases del régimen jurídico de las Administraciones públicas (149.1.18 CE), la legislación procesal (149.1.6 CE) y las condiciones básicas que garantizan la igualdad en el ejercicio de los derechos y en el cumplimiento de los deberes constitucionales $\left(\right.$ art. 149.1.1 CE) ${ }^{20}$.

\section{ORGANIZACIÓN DE LOS PODERES PÚBLICOS}

1. La STC 131/2020 (Pleno), de 22 de septiembre ${ }^{21}$, parte de lo declarado en la STC 83/2020, de 15 de julio ${ }^{22}$ (que, a su vez, se apoya la doctrina sentada por la STC 85/2018, de 19 de julio ${ }^{23}$ ), para resolver el recurso de inconstitucionalidad promovido por más de cincuenta senadores contra la Ley del País Vasco 5/2019, de 4 de abril, de modificación de la Ley 12/2016, de 28 de julio, de reconocimiento y reparación de víctimas de vulneraciones de derechos humanos en el contexto de la violencia de motivación política en la Comunidad Autónoma del País Vasco entre 1978 y $1999^{24}$.

Como en el caso de la STC 85/2018, relativa a una ley foral de parecido propósito y contenido a la ley vasca enjuiciada primero en la STC 83/2020 y luego en la ahora comentada STC 131/2020, la cuestión esencial planteada en este supuesto atańe a si la comisión administrativa creada por el legislador autonómico invade o no la reserva de jurisdicción establecida en el art. 117.3 CE. En aplicación de la doctrina sentada en la STC 83/2020, la STC 131/2020 desestima el recurso en lo referido al ámbito de aplicación de la ley y a los

\footnotetext{
20 Tomás de la Quadra-Salcedo Janini.

21 Véanse, supra, p. 223.

22 Reseñada en Revista Española de Derecho Constitucional, n. ${ }^{\circ}$ 120, 2020, pp. 440-442.

23 Reseñada en Revista Española de Derecho Constitucional, n.o 114, 2018, pp. 217-218.

24 La STC 131/2020 contiene dos votos particulares discrepantes, del magistrado Xiol Ríos y la magistrada Balaguer Callejón, que vienen a remitirse a lo expresado en sus votos particulares a las SSTC 85/2018 y 83/2020.
} 
medios probatorios para acreditar la vulneración de derechos humanos, así como a los principios de actuación de la comisión. Asimismo, desestima, mediante una interpretación de conformidad, la tacha referida al deber de colaboración de los poderes públicos vascos en relación con el «derecho a la verdad» y a la función instructora de la comisión, por entender que esta no puede suponer el desarrollo de actividades dirigidas al esclarecimiento de hechos, autores o circunstancias del delito, constitucionalmente reservadas a la jurisdicción penal (art. 117.3 CE).

2. En la ya citada STC 149/2020 (Pleno), de 22 de octubre, que desestima la cuestión de inconstitucionalidad planteada por la Sala de lo Contencioso-Administrativo del Tribunal Superior de Justicia de Castilla y León contra la Ley 9/2019, de modificación de la Ley 4/1996, de caza en la Comunidad Autónoma de Castilla y León, se aborda también el problema de la reserva de jurisdicción establecida en el art. 117.3 CE. En lo que ahora importa, el órgano judicial sostuvo en su auto de planteamiento de la cuestión que la ley cuestionada ha sido dictada con el propósito de permitir la práctica de la actividad cinegética en Castilla y León y, de este modo, privar de efecto a la medida cautelar suspensiva adoptada respecto del reglamento autonómico que desarrolla la Ley de Caza de esta comunidad autónoma, en el proceso contencioso-administrativo contra esa norma reglamentaria, que se hallaba pendiente de resolución en el momento de aprobarse la ley cuestionada. Por ello, consideraba que esta ley impide a los tribunales el ejercicio de su potestad jurisdiccional de juzgar y hacer ejecutar lo juzgado (art. 117.3 CE), vulnera el derecho a la tutela judicial efectiva (art. 24.1 CE) e infringe el principio de separación de poderes.

La STC 149/2020, FJ 4, rechaza que la ley cuestionada incurra en esas pretendidas infracciones constitucionales por el hecho de regular una materia que antes estaba regulada en un reglamento. Recuerda el TC que en nuestro ordenamiento no existe la reserva reglamentaria, por lo que la ley puede regular cualquier materia; posibilidad esta que no puede verse restringida porque el reglamento que regulaba dicha materia se encuentre impugnado en vía judicial, pues del principio de reserva de jurisdicción (art. 117.3 CE) no puede inferirse la existencia de una correlativa prohibición impuesta al legislador, por la que se condicione su libertad de configuración para elegir el nivel de densidad normativa con que pretende regular una determinada materia. Añade el TC que ni el principio de reserva de jurisdicción exclusiva de jueces y magistrados ni el derecho a la tutela judicial efectiva ni el principio de separación de poderes impiden que el legislador apruebe una ley que pueda afectar 
a procesos judiciales que se encuentren en tramitación en el momento de su entrada en vigor de ese texto legal ${ }^{25}$.

\section{DERECHOS FUNDAMENTALES}

1. En la STC 191/2020, (Pleno), de 17 de diciembre ${ }^{26}$, el recurso de amparo se interpuso contra el art. 2 de la Orden de la Consellería de Educación, Investigación, Cultura y Deporte de la Generalitat Valenciana por la que se establecían las bases reguladoras para la concesión de las becas para la realización de estudios universitarios en las universidades de la Comunidad Valenciana. Según la demandante, una universidad privada, el art. 2 de la orden citada vulneraba los arts. 14, 16 y $27 \mathrm{CE}$, por excluir a las universidades privadas de la citada comunidad del sistema de becas. Explica de inicio el TC que, si bien el objeto de la orden era el de establecer las bases por las que han de regirse las convocatorias de becas para la realización de estudios universitarios en las universidades que integran el sistema universitario valenciano - $y$ que los destinatarios de las becas son los alumnos, no las universidades-, de ello no puede deducirse, sin más, que la universidad recurrente no sea titular de los derechos alegados. Aclara que, si bien los destinatarios de las becas son los alumnos, se produce la exclusión en la orden, tanto de los estudiantes como de los estudios de las universidades privadas, y no son sino estudiantes y estudios los que conforman la universidad, como la recurrente. Por tanto, la desigualdad, justificada o no, se refiere en última instancia a la universidad privada, creada conforme al art. 27.6 CE. En definitiva, la exclusión de los estudiantes de las universidades privadas del régimen de becas previsto en la orden afecta tanto al derecho del titular de la universidad a crear instituciones educativas, art. 27.6 CE, como al de los estudiantes matriculados en dicha universidad, art. 27.5 CE. El TC analiza si hay un trato desigual, si hay término de comparación válido y, en su caso, si la exclusión de las universidades privadas del régimen de becas y ayudas previsto en la orden tiene una justificación objetiva, razonable y proporcionada. De la aplicación de la orden se deriva que los únicos beneficiarios de dicho sistema son los alumnos matriculados en las universidades públicas y que, a sensu contrario, están excluidos de la posibilidad de solicitar dichas becas los alumnos matriculados en las universidades privadas. En consecuencia, no están incluidos en dicho sistema de becas los estudios impartidos en estas, contemplándose tan solo la

25 Herminio Losada González.

26 Véase, supra, p. 232-233. 
posibilidad de incluir determinadas enseñanzas de las universidades privadas dependiendo de lo que se decida en cada convocatoria. Entiende el TC que el legislador orgánico al establecer el régimen jurídico de las universidades no ha distinguido entre universidades públicas y privadas cuando dispone que la universidad realiza el servicio público de la educación superior mediante la investigación, la docencia y el estudio y determina las funciones de la universidad al servicio de la sociedad (art. 1.1 LOU). A ello ańade que las universidades públicas y privadas están sujetas a los mismos requisitos para su creación o reconocimiento; todas las universidades someten las titulaciones que tienen que impartir al mismo procedimiento de aprobación; y el acceso a las universidades, tanto públicas como privadas, tiene una base común. Siendo eso así, considera el TC que la justificación del trato dispar no se deduce ni del tenor de la disposición recurrida ni de su exposición de motivos; no es posible encontrar, por tanto, una finalidad que justifique el establecimiento del tratamiento diferenciado entre las universidades públicas y las universidades privadas. En consecuencia, la exclusión de los alumnos matriculados en las universidades privadas y de las enseñanzas que se imparten en estas del régimen de becas de la Comunidad Valenciana introduce una diferencia entre las universidades del sistema universitario valenciano que carece de la justificación objetiva y razonable que toda diferenciación normativa, por imperativo del art. $14 \mathrm{CE}$, debe poseer para ser considerada legítima. Dicha exclusión, además, se proyecta sobre el art. $27 \mathrm{CE}$, ya que afecta tanto al derecho de las universidades privadas a crear instituciones educativas (art. 27.6 CE) como al derecho de los estudiantes a la educación (art. 27.1 CE), teniendo en cuenta la relación existente entre estos, pues no pueden entenderse los derechos educativos de los estudiantes sin la referencia a las instituciones educativas en las que cursan sus estudios, ni los derechos educativos de las instituciones educativas, en este caso, de la universidad, sin atender a los estudiantes que conforman la comunidad universitaria. La sentencia cuenta con tres votos particulares discrepantes.

2. En la STC 142/2020 (Sala Segunda), de 19 de octubre, el demandante invocaba el derecho a la libertad de expresión (art. 20.1.a CE) del abogado en el ámbito del ejercicio forense del derecho de defensa de su cliente (art. 24.2 $\mathrm{CE}$ ). Argumentaba, en síntesis, que no empleó insulto alguno y que las frases controvertidas fueron desplegadas en el legítimo ejercicio de los indicados derechos fundamentales, al tratarse de una crítica a los argumentos previamente utilizados por el fiscal en un procedimiento en el que el recurrente intervenía como letrado de la defensa. Estima el TC que las afirmaciones por las que fue condenado el recurrente por un delito de injurias cometido contra 
el fiscal interviniente en aquella causa no se produjeron inopinadamente, sino como respuesta a unos calificativos vertidos previamente por el fiscal contra él en un escrito anterior. El tenor de algunas de esas expresiones del fiscal ("estar absolutamente fuera de lugar» y ser «impropios de un letrado» los comentarios que este vertía a la actuación de la magistrada instructora; o utilizar un «tono patético" para fundar la solicitud de una diligencia testifical) revelan, a juicio del TC, un exceso que no tiene justificación.

Por otra parte, el TC considera que no puede calificarse de insulto el mero hecho de indicar que el representante del Ministerio Fiscal «no se ha leído el escrito de recurso»; censurarle «el poco de interés» mostrado, «aunque por ello sufriera alguna molestia»; tildar de «incalificable» su escrito; afirmar que «desconocemos si posee el don de la videncia, clarividencia o adivinación»; o, por fin, acusarlo de «simpleza» en sus juicios, por más que resulte sin duda rechazable y fuera de contexto la referencia hecha al Holocausto del pueblo judío en la Segunda Guerra Mundial, con la que el recurrente pretendía hilar un razonamiento al absurdo para contrarrestar argumentos del fiscal sobre su actuación. Estima el TC que esas expresiones no desbordaron el umbral de protección constitucional, al quedar cubiertas directamente por el canon reforzado del derecho fundamental a la libertad de expresión del abogado en defensa de la posición de su patrocinado. En consecuencia, la posterior condena impuesta al letrado recurrente por la sentencia que impugna resulta vulneradora de aquellos derechos fundamentales. No obstante, el TC entiende que hay un segundo grupo de manifestaciones que merecen distinto tratamiento: el empleo por el abogado recurrente de los adjetivos «insidioso» $\mathrm{y}$ "malintencionado», y, especialmente, la referencia a la lectura por el fiscal de la causa de «alguna revista de contenido inconfesable». Estas expresiones pueden considerarse vejatorias y desde luego innecesarias a los fines de la defensa que ejercía, pues con ellas no se cuestionaba legítimamente la calidad del trabajo desempeñado por el fiscal al oponerse este a lo que dicha defensa planteaba, sino que buscaban su descrédito como persona con el fin de socavar su credibilidad ante el juez a quo. Entiende el TC que esas expresiones rebasan, conforme a su doctrina y a la del Tribunal Europeo de Derechos Humanos, los límites a la libertad de expresión que tiene reconocida el recurrente, pero, ponderando las circunstancias del caso y la singular protección que debe experimentar la libertad de expresión de los abogados, especialmente inmune a restricciones, y el carácter excepcional del castigo penal por expresiones vertidas por aquellos en el ejercicio de su labor profesional, concluye que la condena por delito de injurias implicó un exceso punitivo incompatible con los derechos fundamentales invocados.

También con la libertad de expresión en juego, en la STC 190/2020 (Pleno), de 15 de diciembre, el objeto del recurso de amparo consistía en 
determinar si las sentencias impugnadas, que condenaron al demandante de amparo, como autor responsable de un delito de ultrajes a España del art. 543 del Código Penal, a la pena de siete meses de multa con una cuota diaria de seis euros, vulneraron sus derechos a la libertad ideológica (art. 16.1 CE) y a la libertad de expresión (art. 20.1.a CE). Considera el recurrente que las expresiones que han dado lugar a su condena penal constituyen un ejercicio legítimo de esos derechos fundamentales ${ }^{27}$. Recuerda el TC la doctrina constitucional sobre la libertad de expresión y sus límites. Se razona en las sentencias impugnadas que el encausado actuó con ánimo de menospreciar o ultrajar a la bandera nacional. Se añade en la sentencia de apelación que tales expresiones generaron en la autoridad y personal militar, ajenos al conflicto laboral, «un intenso sentimiento de humillación, proporcional a la gravedad del ultraje». Considera el TC que estos razonamientos ponen de manifiesto que ya la sentencia condenatoria, así como la de apelación que la confirma, hizo un examen de la eventual afectación en el caso concreto del ejercicio legítimo del derecho a la libertad de expresión del acusado. Tiene en cuenta el TC los siguientes factores: el momento en que las expresiones fueron proferidas (momento del izado de la bandera nacional, con interpretación del himno nacional y la guardia militar en posición de arma presentada); la utilización del término "puta» para calificar a la «bandeira», y, además, ambas palabras

27 Se destaca en las resoluciones impugnadas que personas trabajadoras de la empresa encargada del servicio de limpieza de las instalaciones militares del arsenal de Ferrol, que se encontraban en huelga por el impago de sus salarios, se venían concentrando todos los días, a partir del mes de octubre de 2014, frente a la fachada principal del arsenal militar de Ferrol, haciéndolo minutos antes de las 8:00 horas, que era el momento en que tenía lugar la ceremonia del acto solemne de izado de la bandera espańola con interpretación del himno nacional y guardia militar en posición de arma presentada. También queda recogido en aquellas resoluciones que todos los días en que se realizaron aquellas concentraciones los trabajadores en huelga hacían ruido, realizaban pitadas o abucheos, con pitos, sartenes y megáfonos, durante el acto de izado, y proferían consignas como «a bandeira non paga as facturas» para llamar la atención de los viandantes. En tales circunstancias, sobre las 8:00 horas del día 30 de octubre de 2014, en que, como era habitual, tenía lugar el acto de izado de la bandera y las personas en huelga volvían a concentrarse para continuar con sus gritos, protestas y formulación de consignas del mismo tono e intensidad que en jornadas anteriores, en un momento determinado el demandante de amparo, que era representante de un sindicato nacionalista gallego, que estaba en el lugar para defender los intereses laborales de los que realizaban la huelga, valiéndose de un megáfono, dijo las frases «aquí tedes o silencio da puta bandeira» $\mathrm{y}$ «hai que prenderlle lume á puta bandeira». 
insertadas en la expresión "hai que prenderlle lume á puta bandeira», que nunca fue utilizada hasta aquel momento por las personas concentradas; el carácter innecesario de las dos expresiones proferidas para sostener el sentido y alcance de las reivindicaciones laborales defendidas por los concentrados; la falta de vínculo o relación de las expresiones utilizadas con la reivindicación laboral que estaban llevando a efecto las personas concentradas; el «intenso sentimiento de humillación» que, según refiere la sentencia de apelación, sufrieron los militares presentes en el acto, y la manifestación de algunas de las trabajadoras participantes en la concentración, que dijeron «no, eso no». Entiende el TC que las expresiones realizadas configuran el conjunto de un mensaje que no solo conlleva una carga de rechazo hacia la simbología política que representa la enseña nacional, y, por tanto, menospreciativa de los sentimientos de unidad y de afinidad que muchos ciudadanos puedan sentir por aquella, sino que también revela la beligerancia que mostró el recurrente hacia los principios y valores que aquella representa. Además, la expresión de ese deseo supone no ya el de la mera destrucción material de la bandera por el fuego, sino también la difusión a los demás de un sentimiento de intolerancia y de exclusión que se proyecta con su afirmación a todos aquellos ciudadanos que sientan la bandera como uno de sus símbolos de identidad nacional y propios. Reconoce el TC que la doctrina del Tribunal Europeo de Derechos Humanos concede un amplio margen al ejercicio de la libertad de expresión, permitiendo incluso la puesta en escena de actitudes provocadoras, que se utilizan para llamar la atención de la opinión pública y transmitir un mensaje crítico, aunque lo sea con expresiones hirientes o malsonantes para los personajes con relevancia pública. Sin embargo, en el caso de autos, aquellas expresiones no fueron dirigidas contra personas que tuvieran relevancia pública o lo fueran en razón de un asunto o cuestión de interés público. Entiende el TC que cuando, como ocurre en el caso, la expresión de una idea u opinión se hace innecesaria para los fines que legítimamente puedan perseguirse, aparece de improviso y se proyecta un reflejo emocional de hostilidad, el mensaje cuestionado queda fuera del ejercicio regular del derecho a la libertad de expresión. Además el TC llega a la conclusión de que la respuesta penal prevista en el art. $543 \mathrm{CP}^{28}$ resulta proporcionada, ya que la pena de multa fue aplicada en su grado mínimo. La sentencia cuenta con cinco votos particulares discrepantes.

28 El tipo penal recogido en el art. $543 \mathrm{CP}$ castiga con pena de multa de siete a doce meses la conducta consistente en «las ofensas o ultrajes de palabra, por escrito o de hecho a España, a sus comunidades autónomas o a sus símbolos o emblemas, efectuados con publicidad». 
En la STC 192/2020 (Pleno), de 17 de diciembre, el recurso de amparo se dirigía contra las resoluciones judiciales por las que el recurrente resultó condenado a una pena de seis meses de prisión como autor de un delito contra los sentimientos religiosos del art. 523 del Código Penal ${ }^{29}$. El demandante imputaba a ambas resoluciones judiciales la vulneración de los derechos a la libertad ideológica (art. $16 \mathrm{CE}$ ), a la libertad de expresión (art. 20 $\mathrm{CE})$ y a la libertad de reunión (art. $21 \mathrm{CE}$ ), así como la vulneración del principio de legalidad penal (art. 25.1 CE). El TC, tras recordar su jurisprudencia y la del Tribunal Europeo de Derechos Humanos, reitera que el ejercicio de la libertad de expresión no es ilimitado y que sus límites son los que puedan fundamentarse en la protección de otros bienes o valores constitucionales, entre los que, sin duda, está la libertad religiosa y de culto. Explica que en el supuesto enjuiciado los órganos judiciales, en especial el Tribunal Supremo, han valorado, como cuestión previa a la propia aplicación del tipo penal y atendiendo siempre a las circunstancias concurrentes en el caso concreto, si la conducta que se enjuiciaba constituía un ejercicio lícito del derecho fundamental a la libertad de expresión y, en consecuencia, si se justificaba por el valor predominante de esta. En tal examen han llegado a una conclusión negativa, pues tal conducta no quedaba amparada por el ejercicio de ese derecho al poner de manifiesto que constituía un sacrificio de los derechos de terceros que, en el caso, debían prevalecer, atendiendo al modo, tiempo y lugar en que la protesta se hizo efectiva. Es decir, subraya el TC que se ha llevado a cabo una ponderación entre el valor de la libertad de expresión que se ve aquí concernido y las necesidades de protección de otros derechos fundamentales, como la libertad religiosa y de culto, ponderación que se ajusta al ámbito respectivo, atendidas las circunstancias del caso, de uno y otros derechos. Destaca que se debe partir de que el fundamento de la libertad de expresión es el intercambio de ideas, y

29 Se declaró probado que, sobre las 11:00 del día 9 de febrero de 2014, el demandante se encontraba en el interior de la iglesia parroquial de Sant Pere de Banyoles sentado en uno de los bancos, al igual que el grupo de personas en el que se integraba, que contaba con un número de entre diez y quince personas. Una vez comenzó la misa, y sabiendo que con su acción podía ofender los sentimientos religiosos de los feligreses congregados, se levantó al mismo tiempo que sus compańeros y, de manera concertada, arrojó pasquines y gritó la consigna «avortament, lliure y gratuït» (aborto libre y gratuito), en contra del proyecto de reforma de la ley del aborto, al tiempo que se exhibía en la zona del altar una pancarta en la que se leía «Fora rosaris dels nostres ovaris» (Fuera rosarios de nuestros ovarios), paralizando de este modo la celebración de la misa durante dos o tres minutos, tras lo cual abandonó, junto con los demás miembros de grupo, la iglesia. 
por ello resulta que, cuando un grupo de fieles celebra un acto religioso en una iglesia, su lugar de reunión solo es accesible para esa finalidad, relacionada con su culto, y no existe ningún punto de conexión que permita considerar que la ceremonia esté abierta a un intercambio de ideas que reflejen una protesta ejercida por terceros. La celebración de una misa católica es un acto religioso íntimamente relacionado con la dimensión externa de la libertad religiosa, cuyos participantes tienen derecho a no ser inquietados cuando la ejercen, y el Estado tiene el deber de garantizar su pacífica celebración. Considera que la afirmación de que el recurrente ejercía su libertad de expresión no puede prevalecer, porque no existía ningún punto de conexión que permitiera que el recurrente considerara que la ceremonia estaba abierta a un intercambio de ideas con los allí congregados. Además, entiende el TC que el recurrente tenía medios alternativos para comunicar su mensaje sin necesidad de perturbar a los fieles, en tanto que interrumpió el oficio religioso y desplegó una pancarta cuyo contenido, en ese contexto determinado, podía considerarse capaz de herir los sentimientos de dichos fieles, por lo que tal actuación violó el espíritu de tolerancia, que sí respetaron, con su respuesta pacífica, los asistentes a la misa. Por otra parte, dado que nadie tiene un derecho ilimitado a exponer sus ideas donde quiera, y dado que existían otros escenarios abiertos a la posibilidad de un razonable intercambio de ideas, tratar de justificar la conducta con el dato de que la interrupción se prolongó «dos o tres minutos» constituye un argumento muy débil, pues el lugar y el modo en que se ejerce la libertad de expresión no son irrelevantes, cuando, como en el caso, ese ejercicio entra en conflicto con la libertad religiosa y de culto. Por último, tampoco duda el TC de que la sanción, que está prevista en la ley, persigue una finalidad legítima, en cuanto que con ella se garantiza la dimensión colectiva de la libertad religiosa. No resultan indiferentes, afirma el TC, las circunstancias, modo y lugar en los que esa libertad de expresión pretendió ejercerse, lo que, a su vez, legitima la aplicación de medidas sancionadoras o restrictivas dirigidas a la protección de la libertad religiosa y de culto. En suma, concluye el TC que las resoluciones judiciales impugnadas, al imponer la sanción penal, han valorado como cuestión previa si la conducta que se enjuicia constituye un ejercicio lícito del derecho fundamental a la libertad de expresión, teniendo presente su contenido constitucional, y, en ese marco de valoración, han ponderado las diversas circunstancias concurrentes en el caso, tal como impone el principio de supremacía de la Constitución y de respeto a los derechos fundamentales. Tampoco considera el $\mathrm{TC}$, en relación con el principio de legalidad alegado, que el razonamiento empleado incurra en quiebras manifiestamente ilógicas ni que alumbre un resultado extravagante. Por tanto, desestima el amparo. La sentencia cuenta con tres votos particulares discrepantes. 
3. Sobre el art. 17 CE, en la STC 180/2020 (Sala Segunda), de 14 de diciembre, se impugnaba el auto del juzgado de instrucción que acordó la prisión provisional del recurrente por estimar que existían indicios de comisión de un delito de blanqueo de capitales, así como riesgo de fuga y de reiteración delictiva. El demandante de amparo consideraba vulnerado, principalmente, su derecho a la libertad por la omisión de información y acceso a las actuaciones y por la falta motivación de la decisión de prisión provisional. Entiende el TC que el procedimiento seguido para acordar la prisión provisional del demandante no ha respetado las garantías legales de información y acceso a los elementos esenciales de las actuaciones ni las garantías de contradicción e igualdad de armas que exige el principio de jurisdiccionalidad de la medida. Ello porque ni el recurrente ni su letrado tuvieron la oportunidad de conocer con un mínimo de precisión los términos de la petición de prisión del Ministerio Fiscal y no pudieron acceder a las actuaciones en que se asentaba para alegar eficazmente sobre la legalidad de la medida ante el juez instructor que por primera vez decidía sobre su situación personal. Considera el TC que tampoco tuvieron conocimiento y acceso idóneos a las observaciones y base documental esgrimidas por la parte acusadora al oponerse al recurso de apelación, necesarios para cuestionar la legalidad de la prisión acordada. Por todo ello, estima que se ha vulnerado el derecho a la libertad personal por haberse adoptado la prisión sin observancia de la forma prevista en el ordenamiento y sin respetar las garantías procedimentales mínimas que exige la jurisdiccionalidad de la medida.

En la STC 181/2020 (Sala Segunda), de 14 de diciembre, la recurrente se quejaba de la vulneración de su derecho a no declarar (art. 17.3 CE), del incumplimiento del plazo máximo de detención policial (art. 17.2 CE), y de la lesión del derecho de información sobre los motivos de la detención (art. 17.3 CE), del derecho de acceso a las actuaciones policiales (art. 17.3 CE), y del derecho a la garantía del control judicial de la detención (art. 17.4 CE). En primer lugar, descarta el TC la lesión de su derecho a no declarar; explica que el análisis de la diligencia policial de toma de declaración a la recurrente pone de manifiesto que, una vez expresado el deseo de no declarar de la detenida, aun cuando le fueron formuladas tres preguntas, la recurrente hizo un uso efectivo de su derecho. En consecuencia, no aprecia el TC una afectación material del derecho a no declarar. En cuanto al plazo máximo de detención (art. 17.2 CE), la demanda señala que los agentes policiales intervinientes en el atestado dejaron transcurrir más de veinticuatro horas desde la detención, sin que hubiera existido justificación suficiente de esta demora, ni tampoco de la tardanza en la puesta a disposición judicial de la detenida. El TC descarta esta lesión ya que constata que, tanto antes como después de su declaración y 
de la solicitud de habeas corpus, fueron practicadas numerosas diligencias recogidas en el atestado policial, que solo pueden entenderse como necesarias para el esclarecimiento de los hechos y para la determinación de la presunta participación de la demandante en los hechos denunciados. Se trata de diligencias necesarias, practicadas en un plazo razonable, y proporcionadas a la propia naturaleza de los hechos y a la dinámica de una investigación del tipo penal. La demanda denunciaba también la vulneración del derecho a ser informado de los hechos y de los motivos de la detención, porque la recurrente no llegó a tener conocimiento real y efectivo de los hechos objeto de investigación, como tampoco de los motivos de la detención. En este caso, aprecia el TC la lesión del derecho alegado, ya que la diligencia policial de información de derechos no explica la conducta concreta investigada, ni tampoco las fuentes de prueba concurrentes. Recuerda que este derecho no puede quedar reducido a una mera formalidad que haya de ser complementada con el conocimiento de los hechos o con la conducta desplegada, en cada caso concreto, por la persona detenida. En definitiva, la información facilitada a la recurrente no cumplía los requisitos exigidos por la doctrina constitucional para considerar colmado su derecho a conocer los hechos y las razones de su detención. En cuanto a la queja sobre el derecho de acceso a las actuaciones policiales, la recurrente aducía que el abogado designado de oficio tuvo acceso a un contenido mínimo del atestado policial, lo que le impidió el conocimiento de los elementos esenciales relacionados con la detención policial para poder impugnar la legalidad de esta. Entiende el TC que la propia demanda admite que el abogado sí tuvo acceso a las actuaciones policiales, aunque fuera mínimo; además reprocha que la demanda no ha precisado si los elementos del atestado conocidos hasta ese momento permitían a la detenida y a su abogado saber sobre los hechos investigados, los motivos de su detención, de su participación en los hechos y del material incriminatorio hasta entonces recopilado. Por lo tanto, entiende que la recurrente no ha levantado la carga de aportar y argumentar sobre los presupuestos fácticos en los que se basa la invocación formulada, para que el TC se pueda pronunciar al respecto, ya que no le corresponde reconstruir de oficio las demandas. La última lesión invocada por la demanda se refería a la vulneración del derecho a la libertad personal, que la recurrente imputa directamente a la resolución judicial que inadmitió a limine el procedimiento de habeas corpus, así como a la posterior providencia que, igualmente, inadmitió a trámite el incidente de nulidad de actuaciones promovido contra aquel. Recuerda el TC que los únicos motivos constitucionalmente legítimos para no admitir un procedimiento de habeas corpus son los basados en la falta del presupuesto necesario de una situación de privación de libertad no acordada judicialmente o en el incumplimiento de los requisitos formales a los que se 
refiere el art. 4 LOHC. Por tanto, reitera una vez más que el procedimiento de habeas corpus no puede verse mermado en su calidad o intensidad; y que el control judicial de las privaciones de libertad que se realicen a su amparo debe ser plenamente efectivo, y no solo formal; recuerda, asimismo, que es a los órganos judiciales a los que corresponde la esencial función de garantizar el derecho a la libertad mediante el procedimiento de habeas corpus, controlando las privaciones de libertad no acordadas judicialmente; que en esa función están vinculados por la Constitución y que tienen la obligación de aplicar e interpretar las leyes según los preceptos y principios constitucionales, conforme a la interpretación de estos que resulte de las resoluciones dictadas por el TC. Se lamenta el TC del frecuente incumplimiento de la jurisprudencia constitucional que se pone de manifiesto con ocasión de los sucesivos recursos de amparo que se van presentando. Considera que las resoluciones judiciales impugnadas han sido dictadas con manifiesta contravención de la doctrina señalada. El juzgado dictó un auto por el que inadmitió a trámite la solicitud de habeas corpus por un motivo de fondo como era la legalidad de la detención. De manera reiterada, el TC ha declarado que, estando en juego el derecho fundamental a la libertad, la eventual ausencia de una motivación suficiente y razonable de la decisión no supondrá solo un problema de falta de tutela judicial, propio del ámbito del art. 24.1 CE, sino prioritariamente una cuestión que afecta al derecho a la libertad personal, en cuanto que la suficiencia o razonabilidad de una resolución judicial relativa a la garantía constitucional del procedimiento de habeas corpus, prevista en el art. $17.4 \mathrm{CE}$, forma parte de la propia garantía.

4. En la STC 178/2020 (Sala Segunda), de 14 de diciembre, la recurrente en amparo interpuso una demanda de determinación de filiación paterna no matrimonial de su hija, menor de edad, contra su pareja, solicitando prueba de paternidad y que los apellidos de la niña fueran primero el del padre y segundo el de la madre. Asimismo, se pedía que se rectificara el Registro Civil en el sentido expuesto. El demandado accedió a las pretensiones solicitadas. Sin embargo, el día de la vista ante el juzgado de primera instancia, la demandante cambió de petición y solicitó que los apellidos de la menor fueran primero el de la madre y después el del padre. A dicha petición se opuso este al considerarla extemporánea. El juzgado declaró al padre biológico de la menor y estimó la demanda de la madre en el sentido expuesto en la vista oral. Esta decisión fue recurrida en apelación por el padre alegando que no debería haberse accedido al cambio del orden de los apellidos. La audiencia provincial estimó el recurso del padre y se procedió a cambiar los apellidos de la hija. La madre recurrió en casación al Tribunal Supremo, que desestimó el recurso. El 
TC recuerda que en cualquier procedimiento de familia en el que se examinan cuestiones que afectan a bienes o derechos de los menores son normas de orden público, por lo que «no deben prevalecer las pretensiones de los progenitores sino exclusivamente el real beneficio del hijo menor». Por tanto, para valorar qué es lo más beneficioso para el menor, ha de atenderse especialmente a las circunstancias concretas del caso. En este sentido, el TC señala que «la cuestión que debía resolverse en este supuesto no era tanto si el cambio de apellidos era perjudicial para la hija común, como si, partiendo de que ostentaba como primero desde su nacimiento, el apellido de la madre, le era más beneficiosa una alteración de este orden». En consecuencia, «debían haberse tomado en consideración todas las circunstancias que concurren, debiendo justificar razonadamente el órgano judicial de apelación el beneficio que para la menor suponía la alteración de sus apellidos respecto a la situación jurídica y de hecho de la que ya gozaba». La sentencia concluye afirmando que el Tribunal Supremo debió conocer del fondo del asunto planteado para determinar si la resolución que había sido recurrida había protegido el principio del interés del menor. Al no existir un análisis razonado sobre el fondo de la cuestión, el TC considera que se ha lesionado el derecho a la tutela judicial efectiva de la recurrente en amparo y ordena retrotraer las actuaciones al momento inmediatamente anterior al pronunciamiento de la primera de las citadas resoluciones para que el órgano judicial dicte una nueva respetuosa con el derecho fundamental vulnerado.

En la STC 132/2020 (Pleno), de 23 de septiembre, el TC declaró la lesión del derecho a un proceso con todas las garantías del recurrente (art. 24.2 CE), en cuya extradición no se respetó el contenido absoluto del derecho, pues no constaba la renuncia inequívoca del acusado a estar presente en el juicio penal que lo condenó. La Audiencia Nacional acordó, en el marco de una solicitud de extradición, la entrega del recurrente en amparo a las autoridades colombianas para cumplir una condena privativa de libertad que le fue impuesta en su ausencia. El TC considera que las personas condenadas en ausencia tienen derecho a que un tribunal se pronuncie nuevamente sobre el fondo del asunto después de ser oídas, siempre y cuando no haya habido una renuncia voluntaria e inequívoca a estar presente en el acto del juicio. Asimismo, declara que no se dan en este caso los requisitos exigidos por la doctrina establecida en STC 26/2014, de 13 de febrero, que resuelve el recurso de amparo presentado por don Stefano Melloni en relación con una orden europea de detención y entrega, que permitió al TC aclarar su doctrina sobre el contenido absoluto del derecho a un proceso con todas las garantías. Estos requisitos consisten en que la notificación contenga la fecha y hora de la celebración de la vista, y que la notificación haya sido entregada efectivamente de 
tal manera que la persona conozca su contenido. Al no concurrir ninguno de estos requisitos, no puede constatarse la existencia de una renuncia inequívoca a estar presente en el juicio. La entrega a las autoridades colombianas exigía la comprobación de que el juicio en el que se le condenó se hubiera desarrollado con todas las garantías. La sentencia cuenta con un voto particular discrepante.

En la STC 147/2020 (Sala Primera), de 19 de octubre, se analiza otro supuesto de extradición. Las autoridades colombianas solicitaron la extradición del demandante de amparo para su enjuiciamiento por hechos que podrían ser constitutivos de delitos de daños informáticos y cohecho. Esta petición, que tenía como fundamento un escrito de acusación presentado por la Fiscalía colombiana, fue aceptada por la Audiencia Nacional. Sin embargo, el TC otorga el amparo por vulneración de los derechos fundamentales a la tutela judicial efectiva y a un proceso con todas las garantías, en conexión con los de libertad personal y de residencia y circulación. Recuerda el TC que, en el ámbito de la extradición, estos derechos requieren de la concurrencia de una autoridad judicial que garantice la necesidad y proporcionalidad de la medida. Entiende que el escrito de acusación es un acto de parte al que la legislación colombiana no otorga la cualidad de valorar objetiva e imparcialmente las pruebas; por tanto, no puede entenderse que sea suficiente para equipararlo a un acto judicial, faltando, así, el necesario refrendo judicial de la solicitud de la Fiscalía colombiana. En la medida en que las resoluciones judiciales impugnadas aceptaron el escrito de acusación como soporte para la solicitud de extradición, considera el TC que no tutelaron suficientemente la libertad del demandante de amparo.

La STC 165/2020 (Sala Segunda), de 16 de noviembre ${ }^{30}$, aborda el tema de la actividad probatoria. El marido de la recurrente en amparo se personó en el centro de salud del municipio con síntomas de lo que finalmente resultó ser un infarto de miocardio; de ahí fue derivado a un hospital, donde falleció al cabo de diecinueve días. La viuda e hija solicitaron el abono de una indemnización por daños morales, alegando una atención tardía en el tratamiento del infarto. La pretensión indemnizatoria fue denegada en vía administrativa y judicial al resolver la contradicción entre los informes médicos en favor de aquellos que concluían que el tratamiento había sido adecuado. Analiza el TC las consecuencias de no haber aplicado el juzgado el principio de facilidad probatoria respecto del hecho que hubieran podido acreditar los electrocardiogramas que se habían extraviado: la necesidad de que los facultativos del centro de salud activasen el llamado "código infarto", ordenando mucho

30 Véanse, supra, p. 235. 
antes el traslado del paciente a un hospital dotado de los medios necesarios para tratar un infarto. Su negativa sitúa a la recurrente, según esta alega, ante una prueba diabólica e imposible que al no poder cumplir trajo consigo la desestimación de su reclamación patrimonial, produciéndole la lesión de los derechos a la defensa (art. 24.2 CE), y a la tutela judicial efectiva, y a no padecer indefensión (art. 24.1 CE). Recuerda el TC la doctrina de la facilidad probatoria, según la cual, en los casos en los que la Administración dispone de una prueba sobre la cual el demandante funda su derecho, y aquella se niega sin causa justificada a su entrega con el fin de que pueda surtir efecto en el correspondiente proceso, sería contrario al derecho a la tutela judicial efectiva imponerle al interesado la consecuencia de la falta de prueba del hecho. Constata el TC que la prueba principal en la que sustentan su pretensión los recurrentes, primero administrativa y luego procesal, era una documentación en poder de la otra parte, la Administración sanitaria, la cual venía obligada por ley a garantizar su custodia y posible reproducción al formar parte de la historia clínica del paciente. El TC, aplicando la doctrina constitucional sobre el principio de facilidad probatoria, concluye que la recurrente, al no poder acreditar con una prueba fiable que su padre fallecido sufrió un infarto, quedó indefensa para probar en juicio el sustrato fáctico de su pretensión indemnizatoria. Era la Administración sanitaria la que, al ser poseedora del material probatorio relevante (dos electrocardiogramas realizados al difunto en el centro de salud y que evidenciaban que estaba sufriendo un infarto), asumía un deber de custodia que no satisfizo. Al extraviar esa documentación impidió a la demandante probar aquello que a su derecho convenía. Esta conducta irregular contraviene el deber de buena fe y probidad procesal y no puede beneficiar a quien actuó negligentemente ${ }^{31}$.

31 Carlos Ortega Carballo. 